\title{
Detrital zircon geochronology of the Grenville/Llano foreland and basal Sauk Sequence in west Texas, USA
}

\author{
Christopher J. Spencer ${ }^{1,2, \dagger}$, Anthony R. Prave ${ }^{1}$, Peter A. Cawood ${ }^{1}$, and Nick M.W. Roberts ${ }^{2}$ \\ ${ }^{1}$ Department of Earth and Environmental Sciences, University of St. Andrews, North Street, St. Andrews KY16 9AL, UK \\ ${ }^{2}$ NERC Isotopes Geosciences Laboratory, British Geological Survey, Keyworth, Nottingham NG12 5GG, UK
}

\section{ABSTRACT}

U-Pb detrital zircon ages from Mesoproterozoic and Cambrian siliciclastic units in west Texas (USA) constrain the depositional setting, provenance, and tectonic history of the region within a late Mesoproterozoic Grenville foreland basin and the early Paleozoic Sauk transgressive sequence. Two key units, the Hazel and Lanoria Formations, have detrital zircon age spectra dominated by detritus derived from the Grenville orogen (the Llano uplift and eroded equivalents), the ca. 1.4 Ga GraniteRhyolite, and the ca. 1.7-1.6 Ga Yavapai/ Mazatzal provinces. These data, combined with sedimentological data, permit interpreting those formations as the proximal and distal deposits, respectively, of a molasse shed into the Grenvillian foreland basin.

Detrital zircons as young as ca. 520 Ma show that the Van Horn Formation, previously considered to be Precambrian in age, is no older than middle Cambrian. Further, the overall detrital zircon age spectrum of the Van Horn Formation is similar to that of the overlying Cambro-Ordovician Bliss Formation: both indicate derivation from sources that included the ColoradoOklahoma aulacogen, Grenville, GraniteRhyolite, and Yavapai/Mazatzal provinces. The similarities between the depositional history of the Van Horn and Bliss Formations lead us to conclude that the base of the Sauk Sequence in west Texas occurs at the base of the Van Horn Formation. Base-level rise associated with the Sauk transgression affected drainage patterns and sediment deposition along southwestern Laurentia some 20 m.y. earlier than previously assumed.

†E-mail: spenchristoph@gmail.com

\section{INTRODUCTION}

The Grenville orogeny is a record of the assembly of the supercontinent Rodinia. In Laurentia, syn-collisional detritus shed off the evolving Grenville deformation front is preserved in a variety of settings, ranging from widely dispersed extensional basins (e.g., Midcontinent Rift, Fort Wayne Rift) to broad, fluvial aprons hundreds to even thousands of kilometers in width (Cawood et al., 2007; Hadlari et al., 2012; Rainbird et al., 2012, and references therein). In contrast, the preserved lateral extent of foreland basin deposition (as defined by Allen and Allen, 2005) is thought to be limited to a small number of localities proximal to the Grenville thrust front (Santos et al., 2002; Cawood et al., 2007; Baranoski et al., 2009; Rainbird et al., 2012). In west Texas (USA), the late Mesoproterozoic Lanoria and Hazel Formations have been interpreted as having formed in extensional basins (Bickford et al., 2000) or as proximal molasse (Soegaard and Callahan, 1994). Consequently, those units should contain a provenance signal fingerprinting their connection to source terranes exhumed by the Grenville orogeny. We use laser ablation inductively coupled plasma-mass spectrometry (ICP-MS) detrital zircon U-Pb geochronology to assess this prediction and as a potential test of correlations of the formations in west Texas.

Nearly 300 m.y. after the assembly of Rodinia, the supercontinent fragmented. The initial episode of rifting along Laurentia's margins began in the early Neoproterozoic (ca. 780-740 Ma), and extensional tectonism continued for nearly 250 m.y. (Macdonald et al., 2013, and references therein). Thermal subsidence analyses have revealed that, despite this protracted period of continental rifting, the rift-to-drift transition occurred near the time of the Precambrian-Cambrian boundary along both the eastern and western margins of Laurentia (ca. $540 \mathrm{Ma}$ ) (Armin and Mayer, 1983; Bond and Kominz, 1984; Williams and Hiscott, 1987; Cawood et al., 2001).
This is recorded by the progressive onlap and blanketing of North America as preserved in the Sauk Sequence (Sloss, 1963).

The stratigraphic location of the base of the Sauk Sequence has been one of prolonged debate and has generally been ascribed on the basis of sedimentology and biostratigraphy (e.g., Hogan et al., 2011; Peters and Gaines, 2012). In west Texas and New Mexico, its position is placed at the base of the Cambrian-Ordovician Bliss Formation (Hayes, 1972; Amato and Mack, 2012). In New Mexico, this surface is a nonconformity with Mesoproterozoic igneous and metamorphic rocks or the Cambrian Florida Mountains pluton (Clemons, 1988). In west Texas, however, the Bliss Formation overlies the braided fluvial sandstones of the Van Horn Formation, the age of which has been ambiguous but typically considered to be latest Precambrian (Denison, 1980; Davidson, 1980) because of the lack of trace- and/or macrofossils. We use detrital zircon $\mathrm{U}-\mathrm{Pb}$ ages in the Van Horn Formation to assess its maximum depositional age and relation of the Van Horn Formation to the location of the basal Sauk surface in west Texas.

\section{GEOLOGICAL SETTING}

\section{Pre-1.3 Ga Rocks}

Pre-1.3 Ga basement rocks in the southwestern United States belong to the 1.8-1.6 Ga Yavapai/ Mazatzal and 1.5-1.3 Ga Granite-Rhyolite provinces (Fig. 1). These units incorporate arc and arc-related supracrustal rocks as well as A-type granites emplaced behind active continental arcs during intra- and back-arc extension (Karlstrom and Bowring, 1993; Slagstad et al., 2009).

\section{Grenville Orogeny and Sedimentation}

Along the southeast Laurentian margin, the Grenville orogeny (Rivers, 1997; Carr et al., 2000; Chiarenzelli et al., 2010) is attributed to 
Figure 1. Map showing tectonic provinces and distribution of surface exposure of Precambrian and Cambrian rocks (after Whitmeyer and Karlstrom, 2007; Stoeser et al., 2007; position of Precordillera after Thomas, 2006). U-Pb crystallization ages of Mesoproterozoic and Cambrian igneous rocks are also indicated (see text for references). Political boundary base map is from Wikimedia Commons (http:// commons.wikimedia.org/wiki /File:Blank_US_Map.svg) and is used under the Creative Commons Attribution-ShareAlike license. Oklahoma Aul.Oklahoma aulacogen.

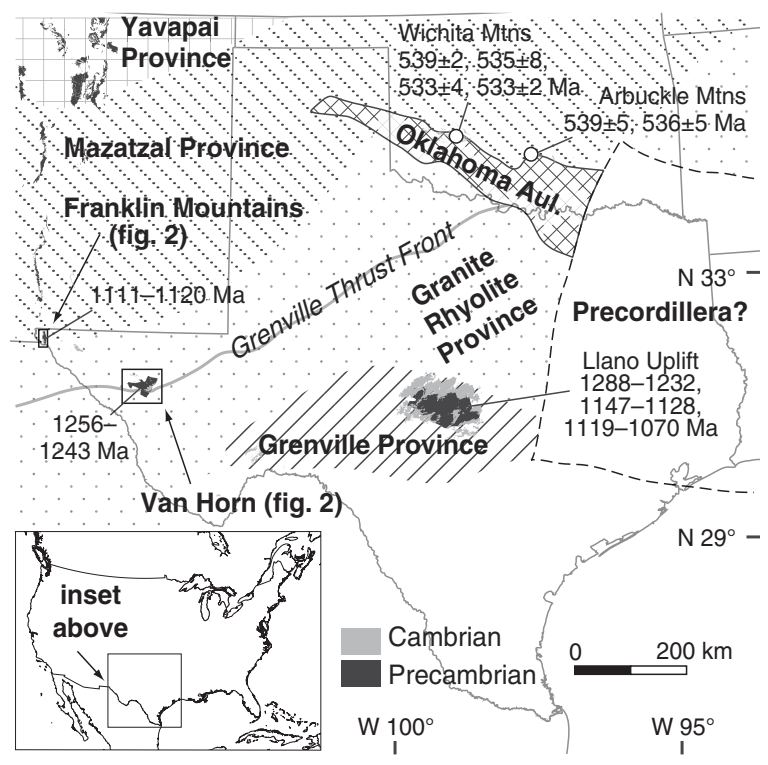

collision with the Kalahari and/or Amazon cratons (Dalziel et al., 2000; Tohver et al., 2006; Jacobs et al., 2008; Hynes and Rivers, 2010). This orogenic episode is archived in rocks forming the broad Grenville province in southeastern Canada, inliers in the Appalachian Mountains, and the Llano uplift of central Texas (Fig. 1) where three main phases of magmatic activity are known: arc volcanism and accretion between 1288 and 1232 Ma, collision-related magmatism between 1150 and $1120 \mathrm{Ma}$, and post-collisional magmatism between 1120 and 1070 Ma (Mosher, 1998).

In west Texas, exposures of Precambrian rocks are restricted to the Franklin Mountains north of El Paso, and the region around Van Horn (Fig. 2). The former contains a metasedimentary succession $\sim 1200$ m thick (Fig. 3), consisting of the basal Castner Marble, the overlying and laterally discontinuous volcanic Mundy Breccia (Bickford et al. 2000), and the Lanoria Formation, a 700-m-thick succession of shallow marine sandstone and mudstone (Shannon et al., 1997; Seeley, 1999). These units are capped by the trachytic to rhyolitic ignimbrites and lavas of the Thunderbird Group with a zircon isotope-dillution-thermal ionization mass spectrometry (ID-TIMS) U-Pb age of $1111 \pm$ 43 Ma (Roths, 1993). The Red Bluff Granite intrudes the entire sequence and has yielded a zircon ID-TIMS U-Pb age of $1120 \pm 35 \mathrm{Ma}$ (Shannon et al., 1997).

In the Van Horn area, the post-1.3 Ga stratigraphy (Fig. 3) begins with the limestonebearing Allamoore Formation, which contains a tuff with zircon ID-TIMS U-Pb ages of $1256 \pm$ $5 \mathrm{Ma}$ (Bickford et al., 2000) and $1255 \pm 2 \mathrm{Ma}$ (Timmons et al., 2005) and is considered to be broadly equivalent to the Castner Marble as well as with the Bass Limestone in the Grand Canyon. Overlying the Allamoore is the Tumbledown Formation, a unit of volcanic and carbonate breccia in which a felsic tuff near the top of the formation has yielded an ID-TIMS U-Pb zircon age of $1243 \pm 10 \mathrm{Ma}$ (Bickford et al., 2000). The Tumbledown Formation is overlain by the Hazel Formation, which is a 3000-m-thick unit of conglomerate and interbedded fine-grained sandstone whose thickness decreases significantly to the north (Bickford et al., 2000).

The initial Neoproterozoic rifting of the western margin of Laurentia is recorded by a ca. 780 Ma magmatic event stretching from Utah to the Yukon (Jefferson and Parrish, 1989; Harlan et al., 2003; Dehler et al., 2010; Spencer et al., 2012; Mahon et al., 2014; Kingsbury-Stewart et al., 2013), whereas rifting and associated magmatism along the eastern Laurentian margin occurred between 760 and $700 \mathrm{Ma}$ (Su et al., 1994; Aleinkoff et al., 1995; Tollo and Hutson, 1996). Thermal subsidence studies show that the eventual rift-to-drift transition occurred along both margins at ca. 620-550 Ma (Williams and Hiscott, 1987; Levy and Christie-Blick, 1991; Thomas, 1991; Aleinikoff et al., 1995; Cawood et al., 2001; Cawood and Pisarevsky, 2006).

\section{Intra-Cratonic Cambrian Magmatism}

The Oklahoma-Colorado aulacogen is interpreted as a failed rift basin (Keller and Stephenson, 2007), which extends from southeast Oklahoma to western Colorado with a spur extending into New Mexico (Fig. 1) and is bounded by the Wichita, Sierra Grande, Cimarron, Tusas, and Uncompahgre uplifts
(McMillan and McLemore, 2004; Keller and Stephenson, 2007). Extensive exposures of Cambrian-age bimodal igneous rocks within the Oklahoma-Colorado aulacogen indicate that crustal extension (Larson et al., 1985; McMillan and McLemore, 2004; Gilbert and Hogan, 2010) propagated broadly cratonward with ages ranging from $539 \mathrm{Ma}$ to $528 \mathrm{Ma}$, based on laser ablation (LA)-ICP-MS and ID-TIMS U-Pb zircon geochronology (Larson et al., 1985; Lambert et al., 1988; Hames et al., 1995; Hogan and Gilbert, 1998; McConnell and Gilbert, 1990; McMillan and McLemore, 2004). In southwestern New Mexico, the Florida Mountains pluton has also been dated by zircon $\mathrm{U}-\mathrm{Pb}$ geochronology as crystallizing at ca. $510 \mathrm{Ma}$ (Amato and Mack, 2012).

\section{Sauk Transgression}

The breakup of Rodinia and subsequent thermal subsidence of the Laurentian margins facilitated deposition of a thick sequence of largely marine sediments (e.g., Bond and Kominz, 1984; Levy and Christie-Blick, 1991). These define the Sauk Sequence (Sloss, 1963), which spans the late Neoproterozoic to mid-Ordovician and blankets approximately half of North America (outcrop and borehole data; Peters and Gaines, 2012).

The Sauk Sequence overlies progressively older units cratonward, from rift/post-riftrelated Neoproterozoic sequences along the margins of Laurentia to Archean-Proterozoic basement in the central regions of the craton (Rankin, 1993). This transgressive episode was long lived, with the base of the Sauk Sequence being $~ 30-40 \mathrm{~m}$.y. younger in the craton interior than at the margins. In west Texas, the base of the Sauk Sequence has been placed at the base of the Cambro-Ordovician Bliss Formation (Hayes, 1972), but, as detailed herein, we suggest it should be placed at the base of the underlying Van Horn Formation.

\section{Van Horn Formation}

The Van Horn Formation near its type locality in Texas consists of $>500 \mathrm{~m}$ of conglomerate with varying amounts of interbedded sandstone and, largely because it is devoid of macro- and trace fossils, has been considered to be Precambrian in age (King and Flawn, 1953). It is arkosic and contains abundant lithic fragments derived from the felsic volcanic rocks of the Thunderbird Group (and its equivalents, e.g., metavolcanic rocks at Pump Station Hills; Thomann, 1981), as well as from the underlying Hazel Formation, and is interpreted as recording deposition in a system of coalescing 

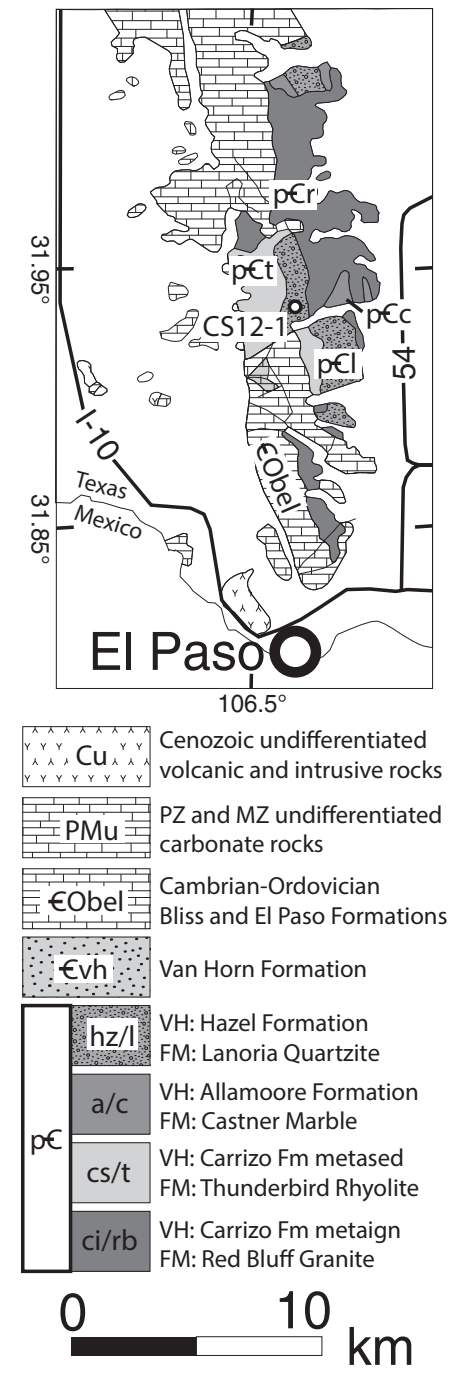

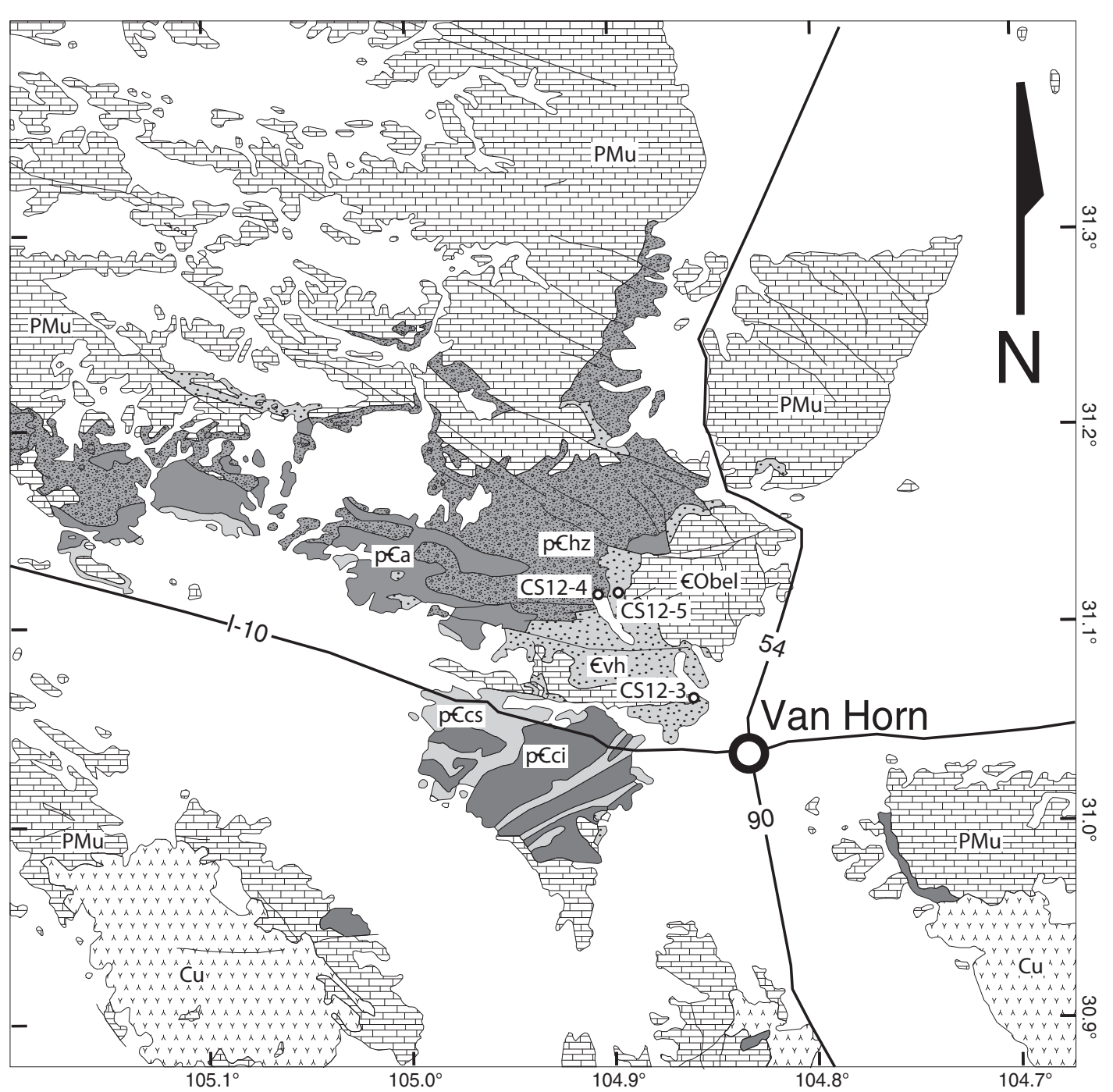

Figure 2. Geologic maps (after Stoeser et al., 2007) of the Franklin Mountains (FM, upper left) and Van Horn (VH) areas; locations of samples collected for detrital zircon analysis are shown. Thick black lines are highways (I-Interstate Highway). PZ—Paleozoic; MZMesozoic; metased-metasedimentary rocks; metaign-metaigneous rocks.

alluvial fans marked by high-gradient streams (McGowen and Groat, 1971). Where exposed, the Van Horn Formation can be seen to infill and mantle an irregular paleotopography formed on the underlying Hazel Formation.

\section{Bliss Formation and Ordovician Carbonates}

The Bliss Formation in Texas is $30-80 \mathrm{~m}$ thick and consists of medium- to fine-grained quartzitic arenite (LeMone, 1969; Davidson, 1980). The contact between the Bliss and the Van Horn has not been resolved and is variously ascribed to being unconformable or depositional (McGowen and Groat, 1971). On the basis of trilobite and conodont biostratigraphy, the Bliss Formation is known to be upper Cam- brian to Lower Ordovician in age (Taylor et al., 2004). Overlying the Bliss Formation is a thick sequence of Ordovician carbonate rocks documenting the final stages of the Sauk transgression (Hayes, 1972) (Fig. 3).

\section{METHODS AND RESULTS}

Four $\sim 5 \mathrm{~kg}$ sandstone samples were collected from the Van Horn and Franklin Mountain regions of west Texas within the Lanoria, Hazel, and Van Horn Formations. Zircons were extracted using standard techniques (i.e., Wilfley table, heavy liquid, Franz magnetic separation), mounted in epoxy resin, and polished to expose the interior of the grains. Zircons were imaged using cathodoluminescence (CL) and back-scattered electron (BSE) techniques
(Fig. 4) prior to analysis. Zircon U-Pb geochronology was performed by LA-single-collector (SC)-ICP-MS at the NERC Isotope Geosciences Laboratory (NIGL), Keyworth, United Kingdom. All unknown and standard data are reported in the GSA Data Repository. ${ }^{1}$

The instrumentation used for analyses comprises a Nu Instruments Attom single-collector high resolution-ICP-MS-coupled to a New Wave Research UP193 solid-state laser ablation system; the full method is described in Thomas et al. (2013). Laser ablation was accomplished

${ }^{1}$ GSA Data Repository item 2014179, U-Pb geochronologic analyses by laser ablation multicollectorinductively coupled plasma-mass spectrometery and analytical parameters, is available at http://www .geosociety.org/pubs/ft2014.htm or by request to editing@geosociety.org. 


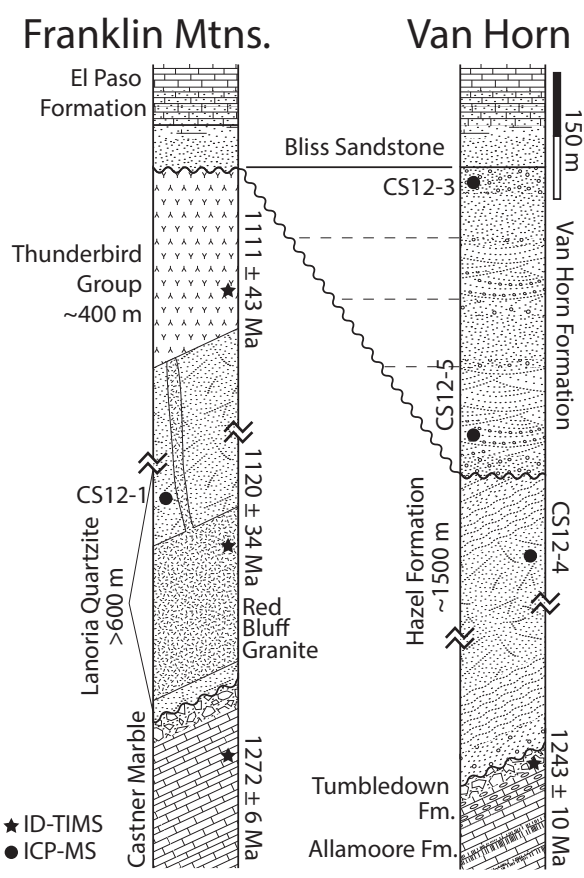

Figure 3. Stratigraphy of the Mesoproterozoic to Cambrian rocks of the Franklin Mountains and Van Horn areas (after Davidson, 1980; Bickford et al., 2000). Westward onlap of the Van Horn Formation inferred from this study. Radiometric ages (marked with stars) are from Shannon et al. (1997) and Bickford et al. (2000). Locations of detrital zircon samples used in this study are marked with circles. ID-TIMS-isotope-dilutionthermal ionization mass spectromety; ICPMS-inductively coupled plasma-mass spectrometry.

with a $25-$ or $35-\mu \mathrm{m}$-diameter spot size with a laser fluence of $2.0-2.2 \mathrm{~J} / \mathrm{cm}^{2}$ at $10 \mathrm{~Hz}$ for 15 seconds of integration (December 2012) or $5 \mathrm{~Hz}$ for 30 seconds (November 2013). On-peak dwell times were adjusted to give the best precision on the $\mathrm{Pb} / \mathrm{Pb}$ and $\mathrm{U} / \mathrm{Pb}$ ratios for an average zircon composition: $200 \mu$ s on ${ }^{202} \mathrm{Hg},{ }^{204} \mathrm{~Pb}$,
${ }^{204} \mathrm{Hg},{ }^{206} \mathrm{~Pb},{ }^{208} \mathrm{~Pb}$, and ${ }^{232} \mathrm{Th} ; 3 \mathrm{~ms}$ on ${ }^{207} \mathrm{~Pb}$; and $4 \mathrm{~ms}$ on ${ }^{235} \mathrm{U}$. ${ }^{238} \mathrm{U}$ was calculated using ${ }^{235} \mathrm{U}$ * 137.818 (Hiess et al., 2012). The $\mathrm{Pb} / \mathrm{Pb}$ and $\mathrm{U} / \mathrm{Pb}$ ratios were normalized to bracketing primary reference materials of 91500 and GJ-1, on the basis of the average measured value of the reference materials compared to the ratio determined by ID-TIMS (Wiedenbeck et al., 1995; Jackson et al., 2004; see also DR2). All Pb/Pb and $\mathrm{U} / \mathrm{Pb}$ reference material analyses have an external reproducibility of $1 \%-2 \%$ (2 standard deviations $[2 \sigma])$. Analyses significantly above ${ }^{204} \mathrm{~Pb}$ (common lead) detection limits ( 600 cps) were rejected.

Systematic uncertainties were propagated using quadratic addition incorporating the internal and external reproducibility of the reference material during each analytical session; these are the isotopic uncertainties of the reference material as determined by ID-TIMS, long-term excess variance of the NIGL Nu Attom SCICP-MS, and decay constant uncertainties (e.g., Schoene et al., 2006).

Given the natural break in U-Pb ages between ca. 1000 and $500 \mathrm{Ma}$ concordance is defined for ages above $700 \mathrm{Ma}$ using the ratio of ${ }^{206} \mathrm{~Pb} /{ }^{238} \mathrm{U}$ and ${ }^{207} \mathrm{~Pb} /{ }^{206} \mathrm{~Pb}$ ages, and ${ }^{206} \mathrm{~Pb} /{ }^{238} \mathrm{U}$ and ${ }^{207} \mathrm{~Pb} /{ }^{235} \mathrm{U}$ ages are used for those younger than $700 \mathrm{Ma}$. The accepted ages were selected from a $95 \%$ concordant subset, wherein the ${ }^{206} \mathrm{~Pb} /{ }^{238} \mathrm{U}$ and ${ }^{207} \mathrm{~Pb} /{ }^{206} \mathrm{~Pb}$ ages are used for zircons younger and older than $700 \mathrm{Ma}$, respectively; this age was chosen because there is a natural gap in the ages of the zircons in these samples. Visualization of U-Pb concordia and zircon ages is achieved using Isoplot 4.0 (Ludwig, 2003) and densityplotter software (Vermeesch, 2012) (Figs. 5 and 6). GPS locations of samples are presented in Table 1.

\section{Lanoria Formation}

One sample of the Lanoria Formation (sample CS12-1) was collected along the Transmountain Road (Fig. 2) from the L3 member of Seeley (1999) in the Franklin Mountains. The sample is a fine- to medium-grained quartz arenite with well-rounded grains and abundant trough and planar cross-bedding. Zircons are mainly colorless with moderate degrees of rounding and sphericity and range in size from 80 to $300 \mu \mathrm{m}$ (Fig. 4). Zircons from this sample yield an age distribution with three main populations at 1235,1460 , and $1840 \mathrm{Ma}\left({ }^{207} \mathrm{~Pb} /{ }^{206} \mathrm{~Pb}\right)$, and subordinate populations of $1.6 \mathrm{Ga}$ and Neoarchean ages (Figs. 5 and 6). Although only 115 of the 172 analyses were $<5 \%$ discordant [using $\left({ }^{206} \mathrm{~Pb} /{ }^{238} \mathrm{U}\right.$ age $) /\left({ }^{207} \mathrm{~Pb} /{ }^{206} \mathrm{~Pb}\right.$ age $\left.)\right]$, all analyses have the same age distributions as the concordant subset. The youngest zircon (1124 \pm $28 \mathrm{Ma}, 3 \%$ discordant) was reanalyzed three times following a re-polishing of the initial ablation pit, which yielded all concordant analyses $(<2 \%$ discordant). The weighted mean of the four analyses is $1094 \pm 9 \mathrm{Ma}$ (mean square weighted deviation, [reduced chi-squared] MSWD = 0.9).

\section{Hazel Formation}

One sample from the Hazel Formation (sample CS12-4) was collected from the upper sandstone unit in the Millican Hills (Fig. 2) of the Van Horn area. The sample is composed of a fine- to coarse-grained litharenite with subrounded sand grains. Zircons from this sample are euhedral to well rounded, range from dark purple to light pink in color, and are $70-500 \mu \mathrm{m}$ in size.

The zircon age distributions show one dominant population at $1120 \mathrm{Ma}$, with two subordinate peaks at 1440 and $1800 \mathrm{Ma}$ (Figs. 5 and 6). There is also a large population of discordant analyses with ca. $1200 \mathrm{Ma}{ }^{207} \mathrm{~Pb} /{ }^{206} \mathrm{~Pb}$ ages. Similar to the Lanoria Formation sample CS12-1, nearly half (64 out of 121) of the analyses are discordant (>5\% discordant), although the discordant age peaks show no major differences from those that are concordant.

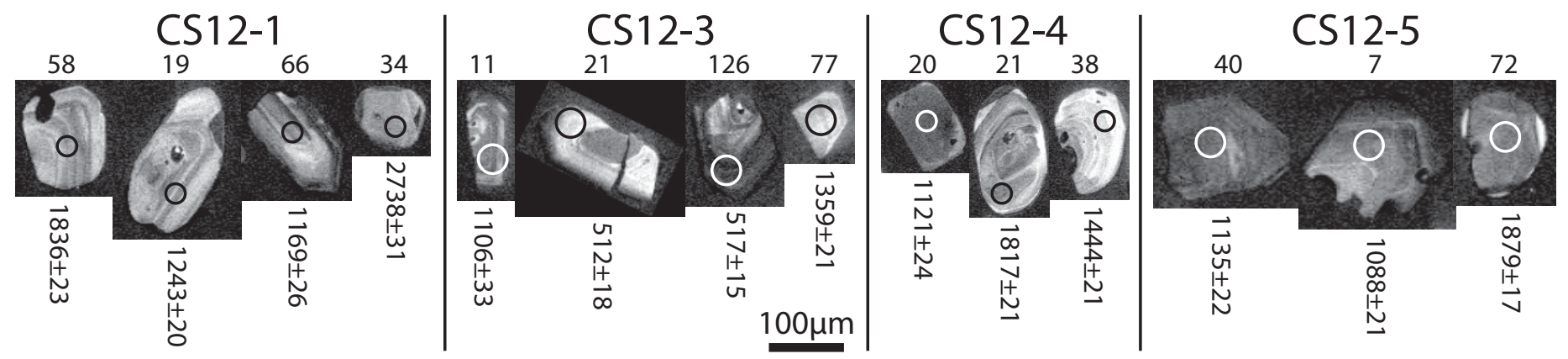

Figure 4. Cathodoluminescence (CL) images with analytical spots and associated ages (in Ma) in representative zircon grains from each sample. CL images have been adjusted only for brightness and contrast. 
Figure 5. U-Pb concordia diagrams of ages (in Ma) of zircon grains from each sample. Note inset for sample CS12-3. Uncertainties are shown at the $2 \sigma$ level. Diagram was constructed using Isoplot software (Ludwig, 2003).

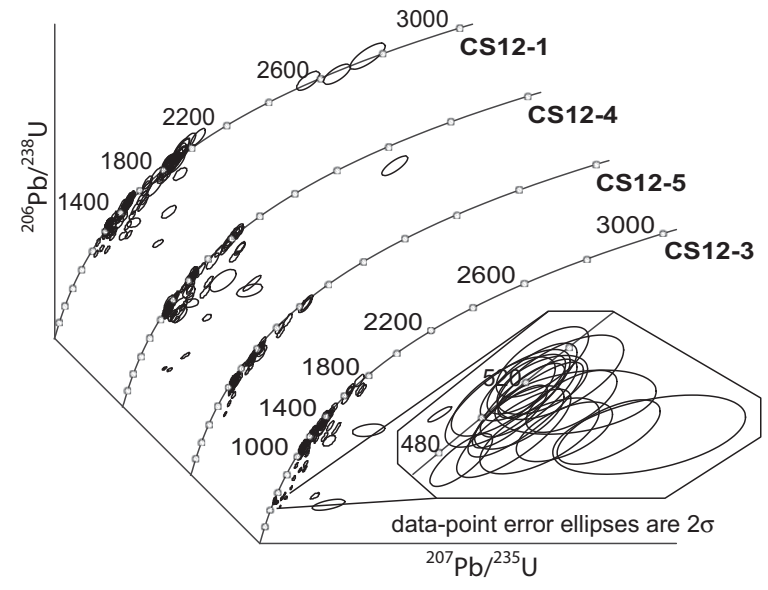

Figure 6. Kernel density estimation (KDE) (black solid line) plots of detrital zircon ages from each sample; only ages $<5 \%$ discordant are used. Gray line represents all analyses regardless of discordance. Open circles below the KDEs represent single analyses. For comparison, similar plots are shown for detrital zircons from the Cambrian Bliss Sandstone east of the Florida Mountains, New Mexico (Amato and Mack, 2012), and late Ediacaran to early Cambrian sediments from the Pie de Palo of Argentina (Naipauer et al., 2010). s-number of samples, $n-$ number of analyses.

lying Hazel Formation; the fragments are abundant in the lower sample. Zircons in both samples are mostly light pink to colorless and range from euhedral to subrounded with several angular fragments. The zircons from the lower Van Horn Formation are 80-900 $\mu \mathrm{m}$ in size, and those from the upper part of the formation range from 50 to $500 \mu \mathrm{m}$.

The age distribution from the lower Van Horn is similar to the age distribution of the underlying Hazel Formation, with dominant age peaks at 1060 and $1400-1480 \mathrm{Ma}$ and a few late Paleoproterozoic grains (Figs. 5 and 6). Similar to the Hazel Formation, there is also a large number of discordant ca. $1180 \mathrm{Ma}$ analyses: the total number of concordant $(<5 \%$ discordant) zircon analyses is 36 of 139 in the lower sample (CS12-5) and 75 of 150 in the upper sample (CS12-3). The upper Van Horn hosts a similar zircon age spectrum (major and subordinate peaks at 1080 and $1400 \mathrm{Ma}$, respectively), but with an additional variably discordant age population at ca. $520 \mathrm{Ma}$ (see DR1). Each of the youngest zircons were reanalyzed multiple times following a re-polishing of the initial ablation pit. They yielded concordant analyses $(<1 \%$ discordant) ranging between $509 \pm 13$ and $533 \pm 12 \mathrm{Ma}\left({ }^{206} \mathrm{~Pb} /{ }^{238} \mathrm{U}\right)$. The weighted means of the four youngest grains overlap within error and are $522 \pm 6 \mathrm{Ma}(\mathrm{n}=4$;

MSWD = 1.9), $521 \pm 6 \mathrm{Ma}(\mathrm{n}=6 ;$ MSWD $=$ $2.0), 519 \pm 10 \mathrm{Ma}(\mathrm{n}=2 ; \mathrm{MSWD}=0.1)$, and $527 \pm 8$ Ma $(\mathrm{n}=3 ;$ MSWD = 0.2) (Fig. 7) The weighted average of all the analyses of the youngest four grains $(n=15)$ is $522 \pm 7 \mathrm{Ma}$ (MSWD $=0.3$ ). It should be noted, however, that a weighted average of a single detrital population assumes that all of the youngest zircons came from a single igneous source of a single age, which is extremely unlikely and ultimately untestable.

\section{DISCUSSION}

\section{Provenance and Correlation of the Lanoria and Hazel Formations}

The post-Grenvillian detrital zircon age spectra of the Lanoria and Hazel Formations are similar and can be linked to proximal provenance areas along the Grenville/Llano deformation front and the Granite-Rhyolite and Yavapai/ Mazatzal provinces (see Fig. 2). The offset in the Grenvillian-age peak from $1120 \mathrm{Ma}$ in the Hazel Formation to $1235 \mathrm{Ma}$ in the Lanoria

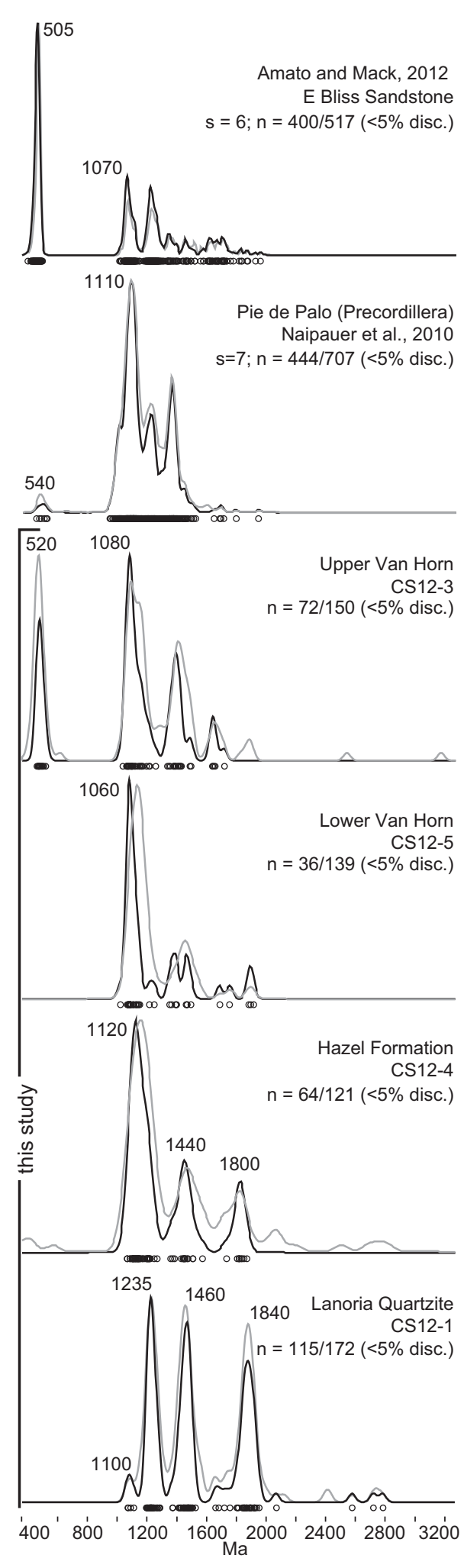

Geological Society of America Bulletin, 
TABLE 1. GPS LOCATIONS AND LITHOLOGY OF SAMPLES FROM THIS STUDY

\begin{tabular}{lccccc}
\hline \hline Sample & Formation & Lithology & Latitude & Longitude & Elevation (ft) \\
\hline CS12-1 & Lanoria & Quartzite & $31^{\circ} 53^{\prime} 9.65^{\prime \prime} \mathrm{N}$ & $106^{\circ} 29^{\prime} 12.05^{\prime \prime} \mathrm{W}$ & 5189 \\
CS12-3 & Upper Van Horn & CGSs & $31^{\circ} 3^{\prime} 48.9^{\prime \prime} \mathrm{N}$ & $104^{\circ} 51^{\prime} 46.2^{\prime \prime} \mathrm{W}$ & 4387 \\
CS12-4 & Hazel & MG to FGSs & $31^{\circ} 6^{\prime} 45.8^{\prime \prime} \mathrm{N}$ & $104^{\circ} 54^{\prime} 12.3^{\prime \prime} \mathrm{W}$ & 4645 \\
CS12-5 & Mid-Van Horn & CGSs & $31^{\circ} 6^{\prime} 59.9^{\prime \prime} \mathrm{N}$ & $104^{\circ} 53^{\prime} 51.1^{\prime \prime} \mathrm{W}$ & 4488 \\
\hline
\end{tabular}

Note: CG—coarse grained; MG-medium grained; FG—-fine grained; Ss—sandstone.

Quartzite likely reflects derivation from different portions of the Grenville orogen. The youngest single-grain $(<1 \%$ discordance) detrital zircons from the Lanoria and Hazel Formations are $1094 \pm 9$ (weighted mean of 4 analyses) and $1079 \pm 27 \mathrm{Ma}$, respectively. A minimum age of the Hazel Formation is constrained by the
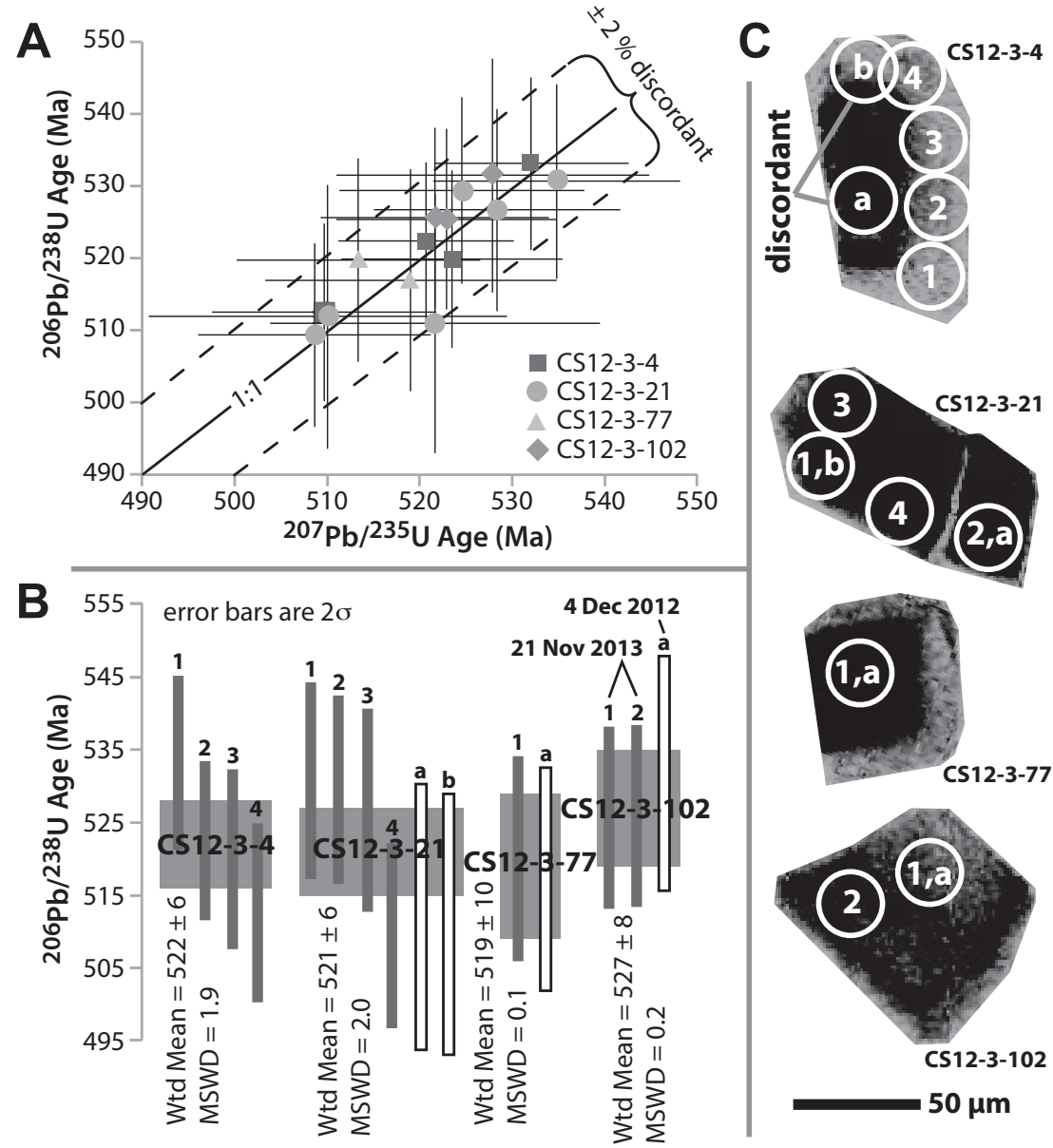

Figure 7. (A) ${ }^{206} \mathrm{~Pb} /{ }^{238} \mathrm{U}$ and ${ }^{207} \mathrm{~Pb} /{ }^{235} \mathrm{U}$ ages (in Ma) of multiple analyses of the youngest detrital zircons within the upper Van Horn Formation (sample CS12-3). The 1:1 line represents perfect concordance between the ${ }^{206} \mathrm{~Pb} /{ }^{238} \mathrm{U}$ and ${ }^{207} \mathrm{~Pb} /{ }^{235} \mathrm{U}$ ages, and the dashed lines represent $\pm 2 \%$ discordance. Uncertainties are $2 \sigma$ (absolute). (B) Weighted mean plots of the youngest zircon ages $\left({ }^{206} \mathrm{~Pb} /{ }^{238} \mathrm{U}\right.$, in Ma) from sample CS12-3. Uncertainties are $2 \sigma$ (absolute). White bars were analyzed in December 2012 and dark gray bars in November 2013. Thick mediumgray bars represent the weighted mean of multiple analyses of single grains. MSWD-mean square weighted deviation (i.e., reduced chi-squared statistic). (C) Inverted color cathodoluminescence images of the grains analyzed. Letters and numbers represent 25 - $\mu \mathrm{m}$-diameter analytical spots from the December 2012 and November 2013 analytical sessions, respectively. Spots from the first session were re-polished to reanalyze the same location. which is imprecisely dated at $1120 \pm 34 \mathrm{Ma}$. The youngest detrital zircon in the Lanoria Formation is within uncertainty of the intrusion age of the Red Bluff Granite (albeit with a younger mean). Despite this, the maximum depositional age of $1094 \pm 9$ Ma for the Lanoria Formation should be used with caution, and if the $1094 \mathrm{Ma}$ zircon does constrain the maximum depositional age, then the two formations may be contemporaneous.

\section{Depositional Model for West Texas Grenvillian Sedimentation}

The Hazel Formation is mostly composed of clast-supported pebble conglomerate with minor interbeds of planar-laminated to crossbedded sandstone and thin mudstone layers having desiccation cracks attesting to subaerial deposition (Soegaard and Callahan, 1994). Systematic variation of pebble composition in the Hazel Formation defines a shift in source material from dominantly footwall to hanging-wall derivation as the Streeruwitz thrust exhumed the Grenvillian basement (Soegaard and Callahan, 1994). The Lanoria Formation outcrop belt is $\sim 180 \mathrm{~km}$ northeast from that of the Hazel Formation. Its facies character, paleocurrent data, and significant northward thinning suggest that sediment was shed from southern highlands (present coordinates) onto a wave- and tide-dominated marine platform (Seeley, 1997, 1999). Previous interpretations have considered the Lanoria and the Hazel Formations as being temporally discrete units (e.g., Bickford et al., 2000; Timmons et al., 2005). Given our findings, with both units displaying similar age spectra and depositional age constraints, and combining those with the sedimentological observations of Seeley (1997, 1999) and Soegaard and Callahan (1994), we hypothesize that the Hazel and Lanoria Formations represent, respectively, a proximal to distal transect of a nonmarine to marine system marginal to the Grenville/Llano deformation front (Fig. 8A).

\section{Provenance and Age of the Van Horn Formation}

The vast majority of clasts $(50 \%-75 \%)$ present in the Van Horn Formation are felsic volcanic detritus, presumably derived from the volcanogenic formations in the west Texas area (McGowen and Groat, 1971). Zircons from the two Van Horn samples analyzed in this study further attest to input from these source regions (ca. 1.0-1.2 Ga). However, the sample collected from the upper part of the Van Horn Formation also contains mid-Cambrianage zircons. The provenance for these zircons 

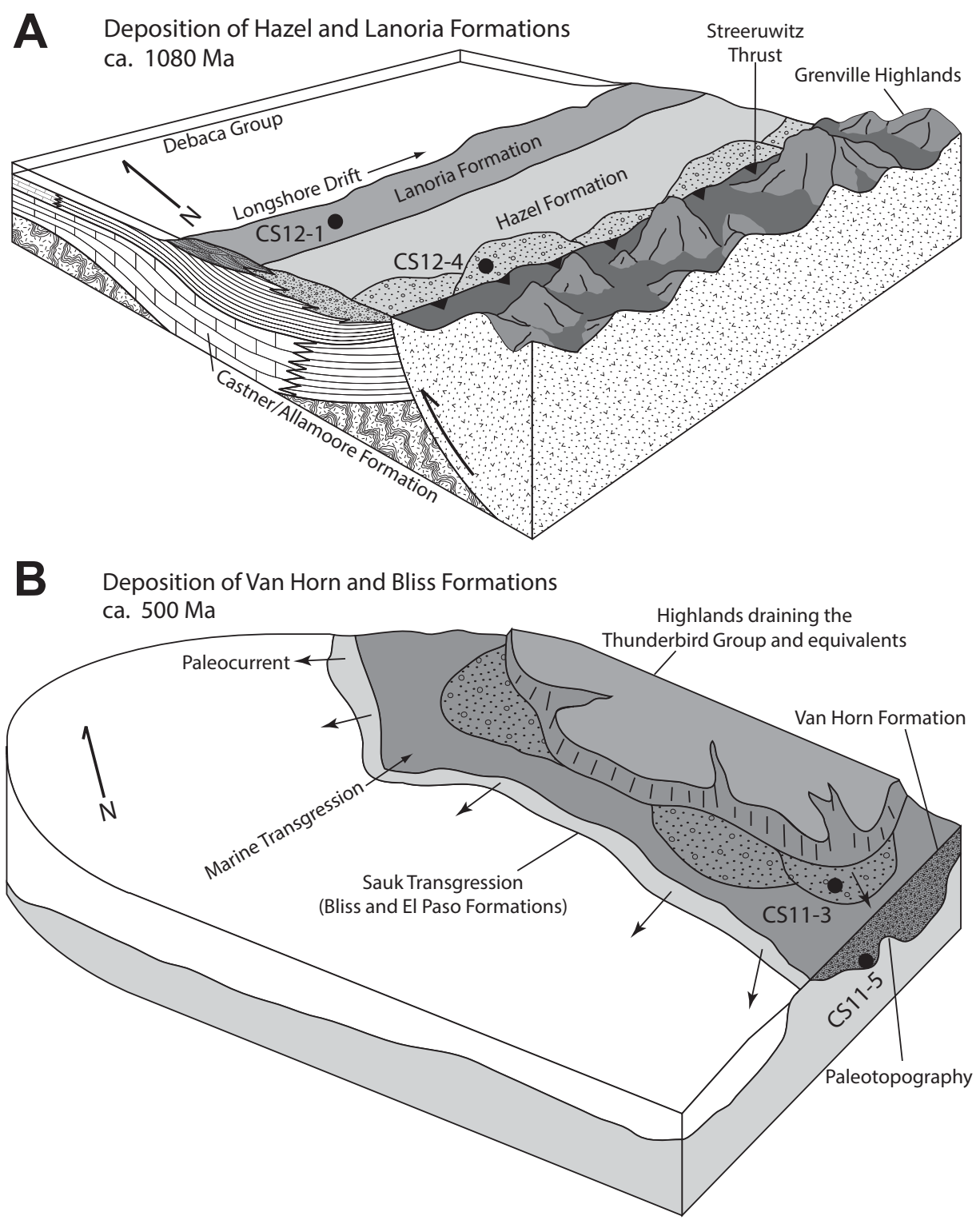

Figure 8. Schematic sedimentary model for the depositional setting of (A) the proximal (Hazel Formation) and distal (Lanoria Formation) deposits of the Grenvillian foreland (after Seeley, 1999; Soegaard and Callahan, 1994) and (B) the Van Horn Formation for the Sauk Sequence transgression in west Texas. Paleocurrent information is taken from Seeley (1999) and Soegaard and Callahan (1994) for A, and from Stewart et al. (2001) and McGowen and Groat (1971) for B.

is somewhat problematic in that paleocurrent data (mostly southwesterly flow directions) would appear to discount the locations of Cambrian granitoids in New Mexico and Oklahoma (Amato and Mack, 2012, and references therein) as sources, hence the source of these zircons remains speculative. Nevertheless, the zircons show that at least the upper Van Horn Formation is no older than Cambrian, not Precambrian, in age. There is no obvious break between the upper and lower parts of the Van

\section{Depositional Model for the Van Horn Formation and Implications for the Sauk Transgression}

The Van Horn Formation is interpreted to be a south-prograding alluvial fan to braided fluvial system that infilled and buried paleotopography (McGowen and Groat, 1971; Fig. 8B). This is similar in depositional style to other siliciclastic units that mark the basal Sauk Sequence such as the Mount Simon Formation in Ohio (Reuter and Watts, 2004; Leetaru and McBride, 2009), Flathead Sandstone of northern Wyoming (Bell, 1970), and Tapeats Sandstone of northern Arizona (Rose, 2006).

As originally noted by Sloss (1963), the age of the basal Sauk Sequence boundary is progressively older toward the cratonic margins. In southeast California, the lower boundary of the Sauk Sequence is either at the base of the lower member of the Wood Canyon Formation (Fedo and Cooper, 2001) or the base of the Stirling Quartzite (Hogan et al., 2011) and corresponds in age to the latest Ediacaran (see Colpron et al., 2002; Macdonald et al., 2013), post-dating the final rift event at ca. 580-560 Ma. The overlying sedimentary succession records the rift-to-drift transition along the southern margin of Laurentia, for example, and from west to east, the Zabriskie, Proveedora, Tapeats, Bolsa, Coronado, and Bliss formations (Figs. 9 and 10). This age progression is also shown by progressively younger concordant detrital zircon $\mathrm{U}-\mathrm{Pb}$ ages from the western margin to the cratonic interior: the youngest concordant zircon within the Wood Canyon Formation of southeast California is $524 \pm 18 \mathrm{Ma}(<2 \%$ discordant, $2 \sigma$, LA-ICP-MS; Stewart et al., 2001; from the geochron.org database), $521 \pm 23 \mathrm{Ma}$ for the Bolsa Formation of south-central Arizona $(<1 \%$ discordant, $2 \sigma$, LA-ICP-MS; Stewart et al., 2001), $503 \pm 14$ Ma for the Coronado Sandstone of southeast Arizona $(<1 \%$ discor-

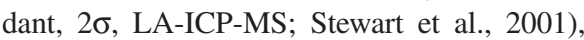
and between $459 \pm 23$ and $468 \pm 5$ Ma for the Bliss Formation of southern New Mexico and west Texas $(<1 \%$ discordant, $2 \sigma$, LA-ICP-MS; Amato and Mack, 2012) (Figs. 9 and 10). It should be noted that the youngest concordant zircon age determined for these units is substantiated by the bio- and lithostratigraphy throughout the basal Sauk Sequence.

Throughout the western margin of Laurentia, the majority of paleoflow directions within the Sauk Sequence are directed to the west with few exceptions (see Stewart et al., 2001; Hogan et al., 2011). However, those for the Sauk Sequence in New Mexico and west Texas display a shift from south-southeast in New Mexico and Texas to west-southwest in northern 


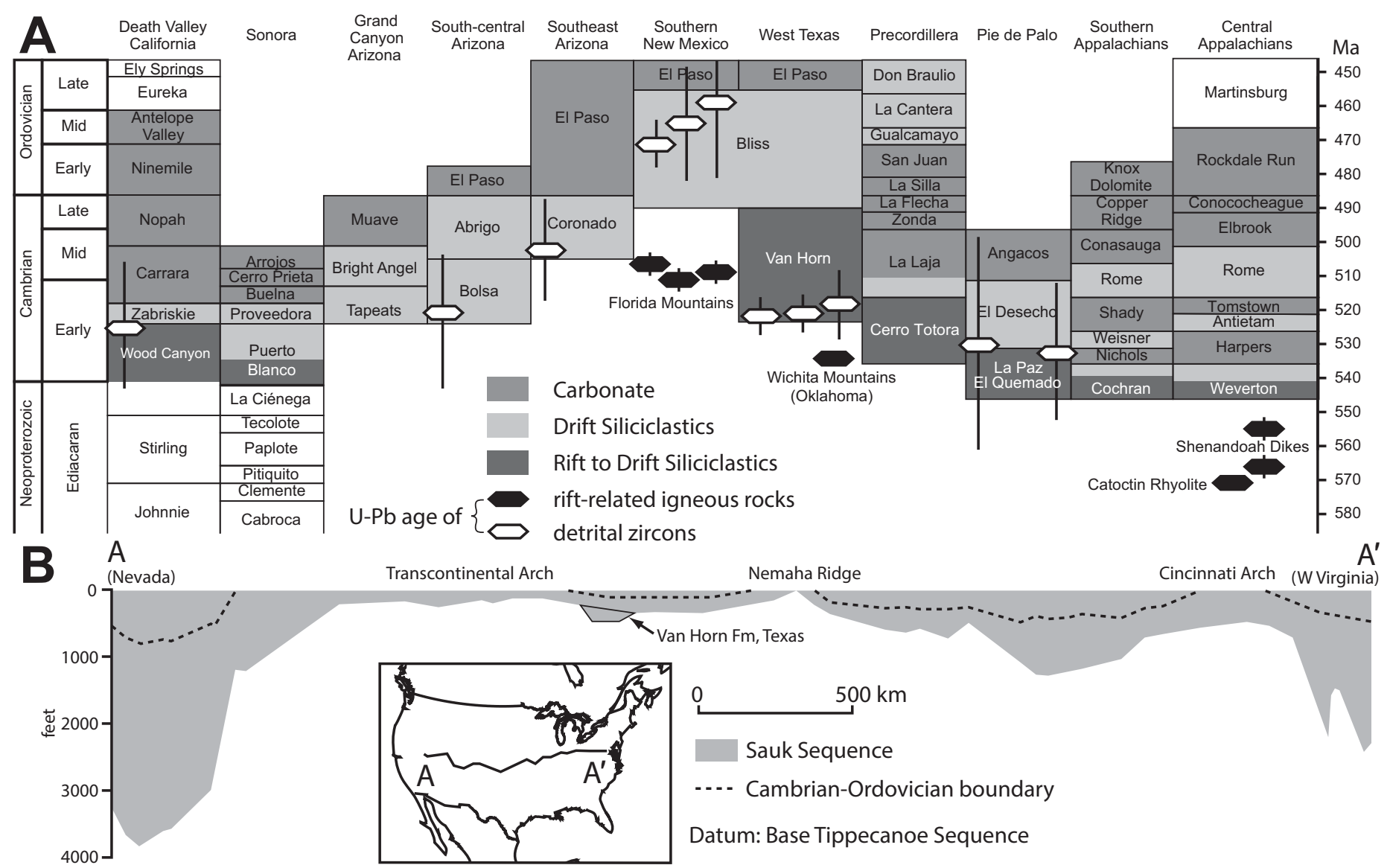

Figure 9. (A) Generalized stratigraphic time-space diagram representative of the Neoproterozoic to Ordovician sedimentary units across south-central Laurentia. The ages of the youngest highly concordant detrital and rift-related igneous zircons (in Ma) are plotted as additional depositional constraints (see Table 2) (disc-discordant). In the case of the Bliss Formation, the ages of the youngest three concordant zircon analyses are plotted (from Amato and Mack, 2012). The weighted averages of multiple analyses of the youngest three zircons are plotted for the Van Horn Formation (see Fig. 7). Uncertainty is displayed at 2 $\sigma$. Various rock types and general depositional settings are as per the following references: Death Valley stratigraphy-Heaman and Grotzinger (1992), Prave (1999), Corsetti and Kaufman (2003), Hogan et al. (2011); Death Valley detrital zircons-Stewart et al. (2001); Sonora stratigraphy—Stewart et al. (2002), Farmer et al. (2005), Stewart (2005), Sour-Tovar et al. (2007); Grand Canyon stratigraphy-Karlstrom et al. (2000, and references therein); south-central and southeast Arizona stratigraphy-Hayes (1972); south-central and southeast Arizona detrital zircons-Stewart et al. (2001); southern New Mexico stratigraphy_Hayes (1972); southern New Mexico detrital/igneous zircons-Amato and Mack (2012); west Texas stratigraphy-Lemone (1969), Hayes (1972); west Texas detrital zircons—-this study; rift-related zircons from the Wichita Mountains-Gilbert and Hogan (2010); Precordillera stratigraphy_Finney et al. (2005); Pie de Palo stratigraphy and detrital zircons-Naipauer et al. (2010); southern Appalachians stratigraphy-Tollo et al. (2010), Tull et al. (2010), Chakraborty et al. (2012); central Appalachians stratigraphy-Astini (1995), Southworth et al. (2009), Burton and Southworth (2010), Tollo et al. (2010); central Appalachians rift-related zircons-Aleinikoff et al., (1995, recalculated by Burton and Southworth, 2010), Southworth et al. (2009). Position of Sonora is restored along the Mojave megashear as per Stewart (2005) and Precordillera/Pie de Palo restored within the Ouachita embayment of Thomas (2006). Geologic time scale is after Walker et al. (2012). (B) Diagrammatic cross-section of the Sauk Sequence through central North America. Note that the datum in the section is the base of the Tippecanoe Sequence. Redrawn from Bally (1989) and Burgess (2008).

Chihuahua (Mexico) and Arizona (McGowen and Groat, 1971; Stewart et al., 2001; Amato and Mack, 2012). This implies a southwestfacing paleoslope or possible topographic high along the eastern edge of the Transcontinental Arch (see Amato and Mack, 2012) during middle Cambrian time. Further, if the southern margin of Laurentia rifted later than the western one (Dalziel et al., 1994; Poole et al., 2005;
Naipauer et al., 2010), an overall westward depositional slope could have been generated due to the earlier onset of differential thermal subsidence in the west.

East of the Transcontinental Arch, the basal Sauk Sequence strata are progressively older eastward (see Thomas, 1991). The three youngest detrital zircon ages from the Van Horn Formation in our study are $519 \pm 10,521 \pm 6$, and
$522 \pm 6 \mathrm{Ma}$ (weighted means of $<1 \%$ discordant analyses; see Fig. 7 and Table 2) and support the overall younging pattern in the maximum depositional ages of the Sauk transgression from the margin of the craton toward the interior. Additionally, in the tectonic reconstructions that place the Precordillera east of Texas (Fig. 1; Thomas and Astini, 1999), that region becomes a viable provenance as indicated by 


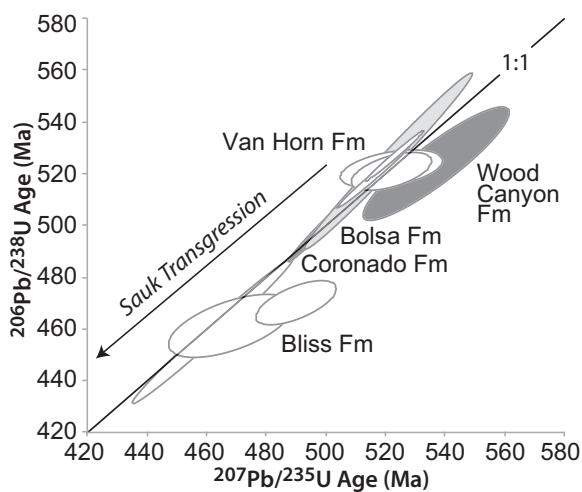

Figure $10 .{ }^{206} \mathrm{~Pb} /{ }^{238} \mathrm{U}$ versus ${ }^{207} \mathrm{~Pb} /{ }^{235} \mathrm{U}$ ages of the youngest detrital zircons from the basal units within the Sauk Sequence in southwestern Laurentia. The 1:1 line represents perfect concordance between the ${ }^{206} \mathrm{~Pb} /{ }^{238} \mathrm{U}$ and ${ }^{207} \mathrm{~Pb} /{ }^{235} \mathrm{U}$ ages. It is important to note that the degree of concordance is consistent with both $\mathrm{U}-\mathrm{Pb}$ isotopic systems, further substantiating the reliability of these ages. References for detrital zircon ages are found in the caption for Figure 9. Uncertainty is displayed at $2 \sigma$.

the El Quemado and El Desecho formations of the Pie de Palo region of western Argentina (Fig. 6) which have yielded concordant zircon ages of $532 \pm 20$ and $531 \pm 31 \mathrm{Ma}$, respectively ( $<4 \%$ discordant) (Naipauer et al., 2010). Several rift-related igneous units exposed east of the Transcontinental Arch also provide important depositional constraints on the Sauk Sequence, such as those in the Wichita Mountains (534 \pm 2 Ma; Gilbert and Hogan, 2010), the Shenandoah felsic dikes $(555 \pm 4 \mathrm{Ma}$ and $567 \pm 4 \mathrm{Ma}$; revised from Aleinkoff et al., 1995, by Burton and Southworth, 2010), and the Catoctin Rhyolite $(571 \pm 1 \mathrm{Ma}$; Southworth et al., 2009). It is noteworthy that the timing of deposition based upon biostratigraphic studies substantiates the maximum depositional age as constrained by the youngest most concordant single zircon grain from this and other detrital zircon studies (e.g., Wood Canyon Formation: Hunt, 1990; Hagadorn et al., 2000; Bolsa Formation: Jones and Bacheller, 1953; Gilluly et al., 1956; Coronado Formation: Ethington and Clark, 1964; Bliss Formation: LeMone, 1969; La Paz and El Desecho formations: Naipauer et al., 2010). However, we note that the youngest zircon age likely represents an underestimation of the maximum depositional age given the assumed normal age distribution of the youngest contributing source of detrital zircons.

The redefinition of the basal Sauk Sequence in west Texas described in this study shifts the

TABLE 2. U-Pb AGES OF THE YOUNGEST ZIRCONS OF THE BASAL SAUK SEQUENCE DISPLAYED IN FIGURES 9 AND 10

\begin{tabular}{|c|c|c|c|c|c|}
\hline & Analysis & ${ }^{206} \mathrm{~Pb} /{ }^{238} \mathrm{U}$ & $2 \sigma$ abs & $207 \mathrm{~Pb} / 235 \mathrm{U}$ & $2 \sigma$ abs \\
\hline 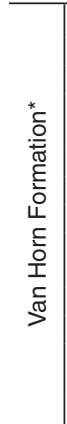 & $\begin{array}{c}\text { CS12-3-4.1 } \\
\text { CS12-3-4.2 } \\
\text { CS12-3-4.3 } \\
\text { CS12-3-4.4 } \\
\text { CS12-3-21.a } \\
\text { CS12-3-21.b } \\
\text { CS12-3-21.1 } \\
\text { CS12-3-21.2 } \\
\text { CS12-3-21.3 } \\
\text { CS12-3-21.4 } \\
\text { CS12-3-77.a } \\
\text { CS12-3-77.2 } \\
\text { CS12-3-102.a } \\
\text { CS12-3-102.1 } \\
\text { CS12-3-102.2 }\end{array}$ & $\begin{array}{l}522 \\
520 \\
533 \\
513 \\
512 \\
511 \\
531 \\
529 \\
509 \\
527 \\
517 \\
520 \\
531 \\
525 \\
526\end{array}$ & $\begin{array}{l}11 \\
12 \\
12 \\
12 \\
18 \\
18 \\
14 \\
13 \\
13 \\
14 \\
15 \\
14 \\
16 \\
13 \\
12\end{array}$ & $\begin{array}{l}521 \\
523 \\
532 \\
510 \\
510 \\
522 \\
535 \\
525 \\
509 \\
528 \\
519 \\
513 \\
528 \\
523 \\
522\end{array}$ & $\begin{array}{r}9 \\
12 \\
11 \\
12 \\
19 \\
18 \\
13 \\
13 \\
13 \\
13 \\
16 \\
13 \\
17 \\
12 \\
12\end{array}$ \\
\hline \multicolumn{2}{|c|}{ Bliss Formation ${ }^{\dagger}$} & $\begin{array}{l}459 \\
461 \\
468\end{array}$ & $\begin{array}{r}23 \\
10 \\
5\end{array}$ & $\begin{array}{l}462 \\
468 \\
474\end{array}$ & $\begin{array}{r}22 \\
17 \\
7\end{array}$ \\
\hline \multicolumn{2}{|c|}{ Coronado Sandstone ${ }^{\S}$} & 503 & 14 & 502 & 12 \\
\hline \multicolumn{2}{|c|}{ Bolsa Quartzite ${ }^{\S}$} & 525 & 11 & 521 & 23 \\
\hline \multicolumn{2}{|c|}{ Wood Canyon Fm } & 524 & 18 & 537 & 20 \\
\hline
\end{tabular}

*this study

${ }^{\dagger}$ Amato and Mack, 2012

\$Stewart et al., 2001

timing of base-level rise and associated marine transgression from the Cambrian-Ordovician boundary (within the Bliss Formation; Lemone, 1969 ) at ca. $490 \mathrm{Ma}$ to ca. 520 Ma within the Van Horn Formation, some several tens of millions of years subsequent to the beginning of the Sauk transgression on the east and west margins of Laurentia at ca. $550 \mathrm{Ma}$ (Kominz, 1995; Fig. 9).

\section{CONCLUSIONS}

Detrital zircon ages and depositional facies determinations from the Hazel and Lanoria Formations in west Texas suggest that these strata respectively represent distal to proximal deposits of the Grenvillian foreland basin, respectively. Detrital zircons were primarily derived from the Llano (Grenville), Granite-Rhyolite, and Yavapai/Mazatzal provinces.

Some 400 m.y. following the Grenville orogeny and formation of Rodinia, Laurentia began rifting along its western and eastern margins (e.g., Li et al., 2008), and the consequent thermal subsidence gave rise to a significant marine transgression responsible for the deposition of the Sauk Sequence (Sloss, 1963). The base of the Sauk Sequence in Texas is herein redefined as the base of the Van Horn Formation, which places the timing of Sauk transgression across this part of the Laurentian craton as mid-Cambrian rather than Early Ordovician as thought previously. Both the Van Horn Formation and the overlying Cambrian Bliss Formation have similar facies characteristics and detrital zircon age distributions with a main peak at ca.
$1150 \mathrm{Ma}$ and other significant peaks attributable to derivation from rocks in the Oklahoma aulacogen and the Granite-Rhyolite and Yavapai/Mazatzal provinces.

\section{ACKNOWLEDGMENTS}

We thank the University of St. Andrews and Natural Environment Research Council (NERC grant NE/J021822/1) for funding support. The NERC Isotope Geosciences Facilities Steering Committee (IP-1326-0512) provided additional funding support. We would like to acknowledge Editor Nancy Riggs, Associate Editor Jeff Amato, Pat Bickford, Valbone Memeti, and two anonymous reviewers for their detailed and useful reviews of this manuscript that considerably improved clarity and style. We would also like to thank Chris Hawkesworth for helpful comments and acknowledge Darice McVay for graciously providing access to the Van Horn Formation, which is largely confined to the McVay Ranch.

\section{REFERENCES CITED}

Aleinikoff, J.N., Zartman, R.E., Walter, M., Rankin, D.W., Lyttle, T., and Burton, W.C., 1995, U-Pb ages of metarhyolites of the Catoctin and Mount Rogers formations, central and southern Appalachians: Evidence for two pulses of Iapetan rifting: American Journal of Science, v. 295 , p. $428-454$.

Allen, P., and Allen, J., 2005, Basin Analysis: Principles and Applications: London, UK, Blackwell Publishing, $642 \mathrm{p}$.

Amato, J.M., and Mack, G.H., 2012, Detrital zircon geochronology from the Cambrian-Ordovician Bliss Sandstone, New Mexico: Evidence for contrasting Grenville-age and Cambrian sources on opposite sides of the Transcontinental Arch: Geological Society of America Bulletin, v. 124, p. 1826-1840, doi:10.1130 /B30657.1.

Armin, R., and Mayer, L., 1983, Subsidence analysis of the Cordilleran miogeocline: Implications for timing of late Proterozoic rifting and amount of extension: Geology, v. 11, p. 702-705, doi: 10.1130/0091-7613 (1983) $11<702$. 
Astini, R., 1995, The early Paleozoic evolution of the Argentine Precordillera as a Laurentian rifted, drifted, and collided terrane: A geodynamic model: Geological Society of America Bulletin, v. 107, p. 253-273, doi 10.1130/0016-7606(1995) 107<0253:TEPEOT>2.3 $\mathrm{CO} ; 2$.

Bally, A.W., 1989, Basins and subsidence-A summary, in Bally, A.W., Bender, P.L., McGetchin, T.R., and Walcott, R.I., eds., Geology of North America-An Overview: Boulder, Colorado, Geological Society of America, The Geology of North America, v. A, p. 397-446.

Baranoski, M.T., Dean, S.L., Wicks, J.L., and Brown, V.M. 2009 , Unconformity-bounded seismic reflection sequences define Grenville-age rift system and foreland basins beneath the Phanerozoic in Ohio: Geosphere, v. 5, p. 140-151, doi:10.1130/GES00202.1.

Bell, L.H., 1970, Depositional history of the Cambrian Flathead Sandstone, Park County, Wyoming, in Enyert, R.L., Wagner, R.L., Renfro, A.R., and Laraway, W.H., eds., Symposium on Wyoming sandstones: Their Economic Importance-Past, Present and Future; 22nd Annual Field Conference Guidebook: Wyoming Geological Association, p. 115-131.

Bickford, M., Soegaard, K., Nielsen, K.C., McLelland, J.M. 2000, Geology and geochronology of Grenville-age rocks in the Van Horn and Franklin Mountains area, west Texas: Implications for the tectonic evolution of Laurentia during the Grenville: Geological Society of America Bulletin, v. 112, p. 1134-1148, doi:10.1130 /0016-7606(2000)112<1134:GAGOGR>2.0.CO;2.

Bond, G.C., and Kominz, M.A., 1984, Construction of tectonic subsidence curves for the early Paleozoic miogeocline, southern Canadian Rocky Mountains: Implications for subsidence mechanisms, age of breakup, and crustal thinning: Geological Society of America Bulletin, v. 95, p. 155-173, doi:10.1130/0016-7606 (1984) $95<155$ :COTSCF $>2.0 . \mathrm{CO} ; 2$

Burgess, P., 2008, Phanerozoic evolution of the sedimentary cover of the North American craton, in Miall, A.D. ed., The Sedimentary Basins of the United States and Canada: Oxford, UK, Elsevier, Sedimentary Basins of the World, v. 5, p. 31-63, doi:10.1016/S1874-5997 (08)00002-6.

Burton, W., and Southworth, S., 2010, A model for Iapetan rifting of Laurentia based on Neoproterozoic dikes and related rocks, in Tollo, R.P., Bartholomew, M.J., Hib bard, J.P., and Karabinos, P.M., eds., From Rodinia to Pangea: The Lithotectonic Record of the Appalachian Region: Geological Society of America Memoir 206, p. 455-476, doi:10.1130/2010.1206(20).

Carr, S.D., Easton, R.M., Jamieson, R.A., and Culshaw, N.G., 2000, Geologic transect across the Grenville orogen of Ontario and New York: Canadian Journal of Earth Sciences, v. 37, p. 193-216, doi:10.1139/e99 -074 .

Cawood, P.A., and Pisarevsky, S.A., 2006, Was Baltica right-way-up or upside-down in the Neoproterozoic? Journal of the Geological Society, v. 163, p. 753-759, doi:10.1144/0016-76492005-126.

Cawood, P., McCausland, P.J.A., Dunning, G.R., 2001, Opening Iapetus: Constraints from the Laurentian margin in Newfoundland: Geological Society of America Bulletin, v. 113, p. 443-453, doi:10.1130/0016-7606 (2001) $113<0443$ :OICFTL $>2.0$. CO; 2 .

Cawood, P.A., Nemchin, A.A., Strachan, R., Prave, T., and Krabbendam, M., 2007, Sedimentary basin and detrital zircon record along East Laurentia and Baltica during assembly and breakup of Rodinia: Journal of the Geological Society, v. 164, p. 257-275, doi:10.1144/0016 -76492006-115.

Chakraborty, S., Moecher, D.P., and Samson, S.D., 2012, Provenance of the Lower Ocoee Supergroup, eastern Great Smoky Mountains: Geological Society of America Bulletin, v. 124, p. 1278-1292, doi:10.1130 /B30578.1.

Chiarenzelli, J., Regan, S., Peck, W.H., Selleck, B.W., Cousens, B., Baird, G.B., and Shrady, C.H., 2010, Shawinigan arc magmatism in the Adirondack Lowlands as a consequence of closure of the Trans-Adirondack backarc basin: Geosphere, v. 6, p. 900-916, doi 10.1130/GES00576.1.
Clemons, R.E., 1988, Geology of the Florida Mountains, southwestern New Mexico: New Mexico Bureau of Mines and Mineral Resources Memoir 43, $112 \mathrm{p}$

Colpron, M., Logan, J.M., and Mortensen, J.K., 2002, U-Pb zircon age constraint for late Neoproterozoic rifting and initiation of the lower Paleozoic passive margin of western Laurentia: Canadian Journal of Earth Science, v. 39 , p. $133-143$

Corsetti, F.A., and Kaufman, A.J., 2003, Stratigraphic investigations of carbon isotope anomalies and Neoproterozoic ice ages in Death Valley, California: Geological Society of America Bulletin, v. 115, p. 916-932, doi: 10.1130/B25066.1.

Dalziel, I., Dalla Salda, L., and Gahagan, L., 1994, Paleozoic Laurentia-Gondwana interaction and the origin of the Appalachian-Andean mountain system: Geological Society of America Bulletin, v. 106, p. 243-252, doi:10 1130/0016-7606(1994)106<0243:PLGIAT>2.3.CO;2.

Dalziel, I., Mosher, S., and Gahagan, L., 2000, LaurentiaKalahari collision and the assembly of Rodinia: The Journal of Geology, v. 108, p. 499-513, doi:10.1086 1314418 .

Davidson, D., 1980, Precambrian geology of the Van Horn area, Texas, in Dickerson, P.W., Hoffer, J.M., and Callender, J.M., eds., New Mexico Geological Society Guidebook, 31st Field Conference, p. 151-154.

Denison, R.E., 1980, Pre-Bliss (P€) Rocks in the Van Horn Region, Trans-Pecos Texas: New Mexico Geological Society Guidebook, 31st Field Conference, p. $155-158$

Ethington, R.L., and Clark, D.L., 1964, Conodonts from the El Paso Formation (Ordovician) of Texas and Arizona: Journal of Paleontology, v. 38, p. 685-704.

Farmer, G., Bowring, S., Matzel, J., Maldanado, G., Fedo, C., and Wooden, J., 2005, Paleoproterozoic Mojave province in northwestern Mexico? Isotopic and $\mathrm{U}-\mathrm{Pb}$ zircon geochronologic studies of Precambrian and Cambrian crystalline and sedimentary rocks, Caborca, Sonora, in Anderson, T.H., Nourse, J.A., McKee, J.W., and Steiner, M.B., eds., The Mohave-Sonora Megashear Hypothesis: Development, Assessment, and Alternatives: Geological Society of America Special Paper 393, p. 183-198, doi:10.1130/0-8137-2393-0 183.

Fedo, C.M., and Cooper, J.D., 2001, Sedimentology and sequence stratigraphy of Neoproterozoic and Cambrian units across a craton-margin hinge zone, southeastern California, and implications for the early evolution of the Cordilleran margin: Sedimentary Geology, v. $141-142$, p. $501-522$, doi:10.1016/S0037-0738 (01)00088-4.

Finney, S., Peralta, S., Gehrels, G., and Marsaglia, K., 2005, The Early Paleozoic history of the Cuyania (greater Precordillera) terrane of western Argentina: Evidence from geochronology of detrital zircons from Middle Cambrian: Geologica Acta, v. 3, p. 339-354.

Gilbert, M., and Hogan, J., 2010, Our favorite outcrop: The striking but enigmatic granite-gabbro contact of the Wichita Mountains igneous province: The Journal of the Oklahoma Geological Society, v. 61, p. 130-134.

Gilluly, J., Palmer, A.R., Williams, J.S., and Reeside, J.B., 1956, General geology of central Cochise County, Arizona, with sections on age and correlation: U.S. Geological Survey Professional Paper 281, 169 p.

Hadlari, T., Davis, W.J., Dewing, K., Heaman, L.M., Lemieux, Y., Ootes, L., Pratt, B.R., and Pyle, L.J., 2012, Two detrital zircon signatures for the Cambrian passive margin of northern Laurentia highlighted by new U-Pb results from northern Canada: Geological Society of America Bulletin, v. 124, p. 1155-1168, doi: 10.1130/B30530.1.

Hagadorn, J.W., Fedo, C.M., and Waggoner, B.M., 2000, Early Cambrian Ediacaran-type fossils from California: Journal of Paleontology, v. 74, p. 731-740, doi: 10.1666/0022-3360(2000)074<0731:ECETFF>2.0 .CO;2.

Hames, W., Hogan, J., and Gilbert, M., 1995, Revised granite-gabbro age relationships, southern Oklahoma aulacogen: Basement Tectonics, v. 12, p. 247-249.

Harlan, S.S., Heaman, L., LeCheminant, A.N., and Premo, W.R., 2003, Gunbarrel mafic magmatic event: A key
780 Ma time marker for Rodinia plate reconstructions Geology, v. 31, p. 1053-1056, doi:10.1130/G19944.1.

Hayes, P., 1972, Stratigraphic nomenclature of Cambrian and Lower Ordovician Rocks of easternmost southern Arizona and adjacent westernmost New Mexico: U.S. Geological Survey Bulletin 1372-B, 32 p.

Heaman, L., and Grotzinger, J., 1992, 1.08 Ga diabase sills in the Pahrump Group, California: Implications for development of the Cordilleran miogeocline: Geology, v. 20, p. 637-640, doi:10.1130/0091-7613(1992)020 $<0637$ :GDSITP $>2.3$.CO;2.

Hiess, J., Condon, D.J., McLean, N., and Noble, S.R., 2012, ${ }^{238} \mathrm{U} /{ }^{235} \mathrm{U}$ systematics in terrestrial uranium-bearing minerals: Science, v. 335 , p. 1610-1614, doi:10.1126 /science. 1215507.

Hogan, E.G., Fedo, C.M., and Cooper, J.D., 2011, Reassessment of the basal Sauk supersequence boundary across the Laurentian craton-margin hinge zone, southeastern California: The Journal of Geology, v. 119, p. 661685, doi:10.1086/661990.

Hogan, J.P., and Gilbert, M.C., 1998, The southern Oklahoma aulacogen: A Cambrian analog for Mid-Proterozoic AMCG (Anorthosite-Mangerite-Charnockite-Granite) complexes?, in Hogan, J.P., and Gilbert, M.C., eds., Basement Tectonics 12: Netherlands, Kluwer Academic Publishers, p. 39-78.

Hunt, D.L., 1990, Trilobite faunas and biostratigraphy of the Lower Cambrian Wood Canyon Formation, Death Valley region, California [M.S. thesis]: Davis, University of California, $140 \mathrm{p}$.

Hynes, A., and Rivers, T., 2010, Protracted continental collision-Evidence from the Grenville Orogen: Canadian Journal of Earth Sciences, v. 47, p. 591-620, doi:10 1139/E10-003.

Jackson, S.E., Pearson, N.J., Griffin, W.L., and Belousova, E.A., 2004, The application of laser ablation-inductively coupled plasma-mass spectrometry to in situ $\mathrm{U}-\mathrm{Pb}$ zircon geochronology: Chemical Geology, v. 211, p. 47-69, doi:10.1016/j.chemgeo.2004.06.017.

Jacobs, J., Pisarevsky, S., Thomas, R.J., and Becker, T., 2008, The Kalahari Craton during the assembly and dispersal of Rodinia: Precambrian Research, v. 160 p. 142-158, doi:10.1016/j.precamres.2007.04.022

Jefferson, C., and Parrish, R., 1989, Late Proterozoic stratigraphy, $\mathrm{U} / \mathrm{Pb}$ zircon ages and rift tectonics, Mackenzie Mountains, northwestern Canada: Canadian Journal of Earth Sciences, v. 26, p. 1784-1801, doi:10.1139/e89 $-151$.

Jones, S.M., and Bacheller, W.D., 1953, Measured sections near Dos Cabezas, Arizona, in Kottlowski, F.E., ed., Guidebook of Southwestern New Mexico, p. 149.

Karlstrom, K.E., and Bowring, S.A., 1993, Proterozoic orogenic history in Arizona, in Reed, J.C., Jr., et al., eds., Precambrian: Conterminous U.S.: Boulder, Colorado, Geological Society of America, Geology of North America, v. C-2, p. 188-211.

Karlstrom, K.E., Bowring, S.A., Dehler, C.M., Knoll, A.H., Porter, S.M., Des Marais, D.J., Weil, A.B., Sharp, Z.D., Geissman, J.W., Elrick, M.B., Timmons, J.M., Crossey, L.J., and Davidek, K.L., 2000, Chuar Group of the Grand Canyon: Record of breakup of Rodinia, associated change in the global carbon cycle, and ecosystem expansion by 740 Ma: Geology, v. 28, p. 619-622, doi:10.1130/0091-7613(2000)28<619:CGOTGC $>2.0$ . $\mathrm{CO} ; 2$.

Keller, G., and Stephenson, R., 2007, The Southern Oklahoma and Dniepr-Donets aulacogens: A comparative analysis, in Hatcher, R.D., Jr., Carlson, M.P. McBride, J.H., and Martínez Catalán, J.R., eds., 4-D Framework of Continental Crust: Geological Society of America Memoir 200, p. 127-143, doi:10.1130 /2007.1200(08)

King, P.B., and Flawn, P.T., 1953, Geology and mineral deposits of pre-Cambrian rocks of the Van Horn area, Texas: Austin, University of Texas Publication 5301, $218 \mathrm{p}$.

Kominz, M., 1995, Thermally subsiding basins and the insulating effect of sediment with application to the Cambro-Ordovician Great Basin sequence, western USA: Basin Research, v. 7, p. 221-233, doi:10.1111/j.1365 -2117.1995.tb00107.x. 
Lambert, D.D., Unruh, D.M., and Gilbert, M.C., 1988, Rb$\mathrm{Sr}$ and $\mathrm{Sm}-\mathrm{Nd}$ isotopic study of the Glen Mountains layered complex: Initiation of rifting within the southern Oklahoma aulacogen: Geology, v. 16, p. 13-17, doi:10.1130/0091-7613(1988)016<0013:RSASNI >2 .3. $\mathrm{CO} ; 2$.

Larson, E.E., Patterson, P.E., Curtis, C., Drake, R., and Mutschler, F.E., 1985, Petrologic, paleomagnetic, and structural evidence of a Paleozoic rift system in Oklahoma, New Mexico, Colorado, and Utah: Geological Society of America Bulletin, v. 96, p. 1364-1372, doi:10.1130/0016-7606(1985)96<1364:PPASEO >2.0 $\mathrm{CO} ; 2$.

Leetaru, H.E., and McBride, J.H., 2009, Reservoir uncertainty, Precambrian topography, and carbon sequestration in the Mt. Simon Sandstone, Illinois Basin Environmental Geosciences, v. 16, p. 235-243, doi:10 .1306/eg.04210909006

LeMone, D., 1969, Lower Paleozoic rocks in the El Paso area: New Mexico Geological Society Guidebook, 20th Field Conference, p. 145-162.

Levy, M., and Christie-Blick, N., 1991, Tectonic subsidence of the early Paleozoic passive continental margin in eastern California and southern Nevada: Geological Society of America Bulletin, v. 103, p. 1590-1606, doi: 10.1130/0016-7606(1991)103<1590:TSOTEP $>2.3$ $\mathrm{CO} ; 2$.

Li, Z.X., Bogdanova, S.V., Collins, A.S., Davidson, A., De Waele, B., Ernst, R.E., Fitzsimons, I.C.W., Fuck, R.A., Gladkochub, D.P., Jacobs, J., Karlstrom, K.E., Lu, S., Natapov, L.M., Pease, V., Pisarevsky, S.A., Thrane, K. and Vernikovsky, V., 2008, Assembly, configuration, and break-up history of Rodinia: A synthesis: Precambrian Research, v. 160, p. 179-210, doi:10.1016/j.precamres.2007.04.021.

Ludwig, K., 2003, Isoplot/Ex version 3.00: A geochronological toolkit for Microsoft Excel: Berkeley, California, Berkeley Geochronology Center.

Macdonald, F., Prave, A., Petterson, R., Smith, E., Pruss, S. Oates, K., Waechter, F., Trotzuk, D., and Fallick, A. 2013, The Laurentian record of Neoproterozoic glaciation, tectonism, and eukaryotic evolution in Death Valley, California: Geological Society of America Bulletin, v. 125, p. 1203-1223, doi:10.1130/B30789.1.

Mahon, R.C., Dehler, C.M., Link, P.K., Karlstrom, K.E., Gehrels, G.E., 2014, Geochronologic and stratigraphic constraints on the Mesoproterozoic and Neoproterozoic Pahrump Group, Death Valley, California: A record of the assembly, stability, and breakup of Rodinia: Geological Society of America Bulletin, v. 126, p. 652-664, doi: 10.1130/B30956.1.

McConnell, D.A., and Gilbert, M.C., 1990, Cambrian extensional tectonics and magmatism within the Southern Oklahoma aulacogen: Tectonophysics, v. 174, p. 147 157, doi:10.1016/0040-1951(90)90388-O.

McGowen, J., and Groat, C., 1971, Van Horn Sandstone, west Texas: An alluvial fan model for mineral exploration: University of Texas at Austin, Bureau of Economic Geology, Report of Investigations 72, $57 \mathrm{p}$

McMillan, N., and McLemore, V., 2004, Cambrian-Ordovician magmatism and extension in New Mexico and Colorado: New Mexico Bureau of Geology and Mineral Resources Bulletin 160, p. 1-12.

Mosher, S., 1998, Tectonic evolution of the southern Laurentian Grenville orogenic belt: Geological Society of America Bulletin, v. 110, p. 1357-1375, doi:10.1130 /0016-7606(1998)110<1357:TEOTSL>2.3.CO;2.

Naipauer, M., Vujovich, G.I., Cingolani, C.A., and McClelland, W.C., 2010, Detrital zircon analysis from the Neoproterozoic-Cambrian sedimentary cover (Cuy ania terrane), Sierra de Pie de Palo, Argentina: Evidence of a rift and passive margin system?: Journal of South American Earth Sciences, v. 29, p. 306-326, doi 10.1016/j.jsames.2009.10.001.

Peters, S.E., and Gaines, R.R., 2012, Formation of the "Great Unconformity" as a trigger for the Cambrian explosion: Nature, v. 484, p. 363-366, doi:10.1038 /nature10969.

Poole, F., Perry, W., Jr., Madrid, R.J., and Amaya-Martínez, R., 2005, Tectonic synthesis of the Ouachita-Marathon-Sonora orogenic margin of southern Laurentia: Stratigraphic and structural implications for timing of deformational events and plate-tectonic model, in Anderson, T.H., Nourse, J.A., McKee, J.W., and Steiner, M.B., eds., The Mohave-Sonora Megashear Hypothesis: Development, Assessment, and Alternatives: Geological Society of America Special Paper 393, p. 543-596, doi:10.1130/0-8137-2393-0.543.

Prave, A., 1999, Two diamictites, two cap carbonates, two $\delta^{13} \mathrm{C}$ excursions, two rifts: The Neoproterozoic Kingston Peak Formation, Death Valley, California: Geology, v. 27, p. 339-342, doi:10.1130/0091-7613 (1999)027<0339:TDTCCT>2.3.CO;2.

Rainbird, R., Cawood, P.A., and Gehrels, G., 2012, The Great Grenvillian Sedimentation Episode: Record of Supercontinent Rodinia's Assembly, in Busby, C., and Azor, A., eds., Recent Advances in the Tectonics of Sedimentary Basins: Blackwell Publishing Ltd., p. 583-601.

Rankin, D., 1993, The volcanogenic Mount Rogers Formation and the overlying glaciogenic Konnarock Formation-Two late Proterozoic units in southwestern Virginia: U.S. Geological Survey Bulletin 2029, 26 p.

Reuter, J., and Watts, D., 2004, An ancient river channel system incised on the Precambrian-Cambrian unconformity beneath Jackson County, Ohio: AAPG Bulletin, v. 88, p. 1041-1047, doi:10.1306/02240403066.

Rivers, T., 1997, Lithotectonic elements of the Grenville province: Review and tectonic implications: Precambrian Research, v. 26, p. 409-420.

Rose, E.C., 2006, Nonmarine aspects of the Cambrian Tonto Group of the Grand Canyon, USA, and broader implications: Palaeoworld, v. 15, p. 223-241, doi:10.1016/j .palwor.2006.10.008

Roths, P.J., 1993, Geochemical and geochronological studies of the Grenville-age (1,250-1,000 Ma) Allamoore and Hazel Formations, Hudspeth and Culberson counties, west Texas, in Soegaard, K, et al, eds., Precambrian Geology of the Franklin Mountains and Van Horn Area, Trans-Pecos Texas: Dallas, Texas, Geological Society of America South Central Section, University of Texas, p. 11-35.

Santos, J., Hartmann, L., McNaughton, N., Easton, R., Rea, R., and Potter, P., 2002, Sensitive high resolution ion microprobe (SHRIMP) detrital zircon geochronology provides new evidence for a hidden Neoproterozoic foreland basin to the Grenville: Canadian Journal of Earth Sciences, v. 39, p. 1505-1515, doi:10.1139/e02 -052 .

Schoene, B., Crowley, J.L., Condon, D.J., Schmitz, M.D., and Bowring, S.A., 2006, Reassessing the uranium decay constants for geochronology using ID-TIMS U-Pb data: Geochimica et Cosmochimica Acta, v. 70, p. 426-445, doi:10.1016/j.gca.2005.09.007.

Seeley, J., 1999, Studies of the Proterozoic tectonic evolution of the southwestern United States [Ph.D. thesis]: El Paso, University of Texas, $321 \mathrm{p}$.

Seeley, J.M., 1997, Stratigraphy and depositional environments of the Middle Proterozoic Lanoria Formation, Franklin Mountains, West Texas (abs.), in Proceedings, Geological Society of America, Rocky MountainSouth Central Joint Section Meeting: El Paso, Texas, Texas A\&M University, $268 \mathrm{p}$.

Shannon, W., Barens, C., and Bickford, M., 1997, Grenville magmatism in west Texas: Petrology and geochemistry of the Red Bluff granitic suite: Journal of Petrology, v. 38, p. 1279-1305, doi:10.1093/petroj/38.10.1279.

Slagstad, T., Culshaw, N.G., Daly, J.S., and Jamieson, R.A., 2009, Western Grenville Province holds key to midcontinental Granite-Rhyolite Province enigma: Terra Nova, v. 21, p. 181-187, doi:10.1111/j.1365-3121 .2009.00871.x.

Sloss, L., 1963, Sequences in the cratonic interior of North America: Geological Society of America Bulletin, v. 74, p. 93-114, doi:10.1130/0016-7606(1963)74[93: SITCIO]2.0.CO;2.

Soegaard, K., and Callahan, D., 1994, Late Middle Proterozoic Hazel Formation near Van Horn, Trans-Pecos Texas: Evidence for transpressive deformation in Grenvillian basement: Geological Society of America Bulletin, v. 106, p. 413-423, doi:10.1130/0016-7606 (1994) 106<0413:LMPHFN>2.3.CO;2.

Sour-Tovar, F., Hagadorn, J., and Huitron-Rubio, T., 2007, Ediacaran and Cambrian index fossils from Sonora,
Mexico: Paleontology, v. 50, p. 169-175, doi:10.1111/j .1475-4983.2006.00619.x

Southworth, S., Bailey, C.M., Eaton, L.S., Hancock, G., Lamoreaux, M.H., Litwin, R.J., Burton, W.C., and Whitten, J., 2009, Geology of the Shenandoah National Park Region: Guidebook for 39th Annual Virginia Geological Field Conference (October 2-3, 2009), 40 p.

Spencer, C.J., Hoiland, C.W., Harris, R.A., Link, P.K., and Balgord, E.A., 2012, Constraining the timing and provenance of the Neoproterozoic Little Willow and Big Cottonwood Formations, Utah: Expanding the sedimentary record for early rifting of Rodinia: Precambrian Research, v. 204-205, p. 57-65, doi:10.1016 /j.precamres.2012.02.009

Stewart, J., 2005, Evidence for Mojave-Sonora megashearSystematic left-lateral offset of Neoproterozoic to Lower Jurassic strata and facies, western United States and northwestern Mexico, in Anderson, T.H., Nourse, J.A., McKee, J.W., and Steiner, M.B., eds., The Mohave-Sonora Megashear Hypothesis: Development, Assessment, and Alternatives: Geological Society of America Special Paper 393, p. 209-231, doi:10.1130 10-8137-2393-0.209.

Stewart, J., Gehrels, G., Barth, A., Link, P., Christite-Blick, N., and Wrucke, C., 2001, Detrital zircon provenance of Mesoproterozoic to Cambrian arenites in the western United States and northwestern Mexico: Geological Society of America Bulletin, v. 112, p. 1343-1356, doi: 10.1130/0016-7606(2001)113<1343:DZPOMT>2.0 $\mathrm{CO} ; 2$.

Stewart, J.H., Amaya-Martínez, R., and Palmer, A.R., 2002, Neoproterozoic and Cambrian strata of Sonora, Mexico: Rodinian supercontinent to Laurentian Cordilleran margin, in Barth, A., ed., Contributions to Crustal Evolution of the Southwestern United States: Geological Society of America Special Paper 365, p. 5-20, doi:10 .1130/0-8137-2365-5.5

Stoeser, D., Green, G., Morath, L., Heran, W., Wilson, A. Moore, D., and Van Gosen, B., 2007, Preliminary integrated geologic map databases for the United States: Central States: Montana, Wyoming, Colorado, New Mexico, North Dakota, South Dakota, Nebraska, Kansas, Oklahoma, Texas, Iowa, Missouri, Arkansas, and Louisiana: U.S. Geological Survey Open-File Report 2005-1351, version 1.0, http://pubs.usgs.gov/of/2005 11351.

Su, Q., Goldberg, S., and Fullagar, P., 1994, Precise U-Pb zircon ages of Neoproterozoic plutons in the southern Appalachian Blue Ridge and their implications for the rifting of Laurentia: Precambrian Research, v. 68, p. 81-95, doi:10.1016/0301-9268(94)90066-3.

Taylor, J.F., Myrow, P.M., Ripperdan, R.L., Loch, J.D., and Ethington, R.L., 2004, Paleoceanographic events and faunal crises recorded in the Upper Cambrian and Lower Ordovician of west Texas and southern New Mexico, in Nelson, E.P., and Erslev, E.A., eds., Field Trips in the Southern Rocky Mountains, USA: Geological Society of America Field Guide 5, p. 167-183, doi:10.1130/0-8137-0005-1.167.

Thomann, W., 1981, Ignimbrites, trachytes, and sedimentary rocks of the Precambrian Thunderbird Group, Franklin Mountains, El Paso, Texas: Geological Society of America Bulletin, v. 92, p. 94-100, doi:10.1130/0016 -7606(1981)92<94:ITASRO>2.0.CO;2.

Thomas, R.J., Roberts, N.M.W., Jacobs, J., Bushi, A.M., Horstwood, M.S.A., and Mruma, A., 2013, Structural and geochronological constraints on the evolution of the eastern margin of the Tanzania Craton in the Mpwapwa area, central Tanzania: Precambrian Research, v. 224 p. 671-689, doi:10.1016/j.precamres.2012.11.010.

Thomas, W., 1991, The Appalachian-Ouachita rifted margin of southeastern North America: Geological Society of America Bulletin, v. 103, p. 415-431, doi:10.1130 /0016-7606(1991)103<0415:TAORMO>2.3.CO;2.

Thomas, W., 2006, Tectonic inheritance at a continental margin: GSA Today, v. 16 , no. 2, p. 4-10.

Thomas, W.A., Astini, R.A., 1999, Simple-shear conjugate rift margins of the Argentine Precordillera and the Ouachita embayment of Laurentia: Geological Society of America Bulletin, v. 111, p. 1069-1079, doi 10.1130/0016-7606(1999)111<1069:SSCRMO>2.3 $\mathrm{CO} ; 2$. 
Timmons, J.M., Karlstrom, K.E., Heizler, M.T., Bowring, S.A., Gehrels, G.E., and Crossey, L.J., 2005, Tectonic inferences from the ca. 1255-1100 Ma Unkar Group and Nankoweap Formation, Grand Canyon: Intracratonic deformation and basin formation during protracted Grenville orogenesis: Geological Society of America Bulletin, v. 117, p. 1573-1595, doi:10.1130/B25538.1.

Tohver, E., Teixeira, W., Van der Pluijm, B., Geraldes, M.C., Bettencourt, J.S., and Rizzotto, G., 2006, Restored transect across the exhumed Grenville orogen of Laurentia and Amazonia, with implications for crusta architecture: Geology, v. 34, p. 669-672, doi:10.1130 /G22534.1.

Tollo, R.P., and Hutson, F.E., 1996, 700 Ma rift event in the Blue Ridge province of Virginia: A unique time constraint on pre-Iapetan rifting of Laurentia: Geology, v. 24, p. 59-62, doi:10.1130/0091-7613(1996)024 $<0059$ :MREITB $>2.3 . \mathrm{CO} ; 2$.

Tollo, R.P., Aleinikoff, J.N., Wooden, J.L., Mazdab, F.K. Southworth, S., and Fanning, C.M., 2010, Thermomagmatic evolution of Mesoproterozoic crust in the Blue Ridge of SW Virginia and NW North Carolina:
Evidence from U-Pb geochronology and zircon geothermometry, in Tollo, R.P., Bartholomew, M.J., Hibbard, J.P., and Karabinos, P.M., eds., From Rodinia to Pangea: The Lithotectonic Record of the Appalachian Region: Geological Society of America Memoir 206, p. 859-896, doi:10.1130/2010.1206(33).

Tull, J.F., Allison, D.T., Whiting, S.E., and John, N.L., 2010, Southern Appalachian Laurentian margin initial drift-facies sequences, in Tollo, R.P., Bartholomew, M.J., Hibbard, J.P., and Karabinos, P.M., eds., From Rodinia to Pangea: The Lithotectonic Record of the Appalachian Region: Implications for margin evolution: Geological Society of America Memoir 206, p. 935-956, doi:10.1130/2010.1206 (36).

Vermeesch, P., 2012, On the visualisation of detrital age distributions: Chemical Geology, v. 312-313, p. 190-194, doi:10.1016/j.chemgeo.2012.04.021.

Walker, J.D., Geissman, J.W., Bowring, S.A., and Babcock, L.E., compilers, 2012, Geologic Time Scale v. 4.0: Boulder, Colorado, Geological Society of America, doi:10.1130/2012.CTS004R3C.
Whitmeyer, S., and Karlstrom, K., 2007, Tectonic model for the Proterozoic growth of North America: Geosphere, v. 3, p. 220-259, doi:10.1130/GES00055.1.

Wiedenbeck, M., Allé, P., Corfu, F., Griffin, W.L., Meier, M., Oberli, F., Von Quadt, A., Roddick, J.C., and Spiegel, W., 1995, Three natural zircon standards for U-Th-Pb, Lu-Hf, trace element, and REE analyses: Geostandards Newsletter, v. 19, p. 1-23, doi:10.1111/j.1751-908X .1995.tb00147.x.

Williams, H., and Hiscott, R., 1987, Definition of the Iapetus rift-drift transition in western Newfoundland: Geology, v. 15 , p. 1044-1047, doi:10.1130/0091-7613(1987)15 $<$ 1044:DOTLRT>2.0.CO;2.

SCIENCE Editor: NANCy Riggs

AsSOCIATE EDIToR: JeFFrey M. Amato

ManusCRIPT Received 9 March 2013

Revised Manuscript Received 1 March 2014

MANUSCRIPT ACCEPTED 20 March 2014

Printed in the USA 